\title{
Den vördade Tsangpa Herukas sångsamling
}

Den önskeuppfyllande juvelen som visar den allvetandes väg

DEN STORA FARKOSTENS VERKLIGA MENING

\section{Namo guru!}

I enlighet med den store ojämförlige Sharawa Sangye Senges instruktioner vistades den mäktige yogin - Bloddrickaren, Herukan som smyckar sig med benornament - i Lachis snöhöljda bergsområde. Medan han befann sig i klarhetens tillstånd - bortom kommande och gående - offrade han sitt obefläckade förverkligande till de tidigare mästarna genom denna sång som uttrycker den insikt som hade uppstått inom honom:

Emaho!

Den segerrike Hevajra

är det egna sinnet - rent till sitt ursprung.

I detta tillstånd av enkelhet finns varken tomhet eller icke-tomhet.

Tidigare förstod jag inte visdomen som uppstår av sig själv - enkelheten.

När jag mediterade gjorde villfarelsen inom mig att jag uppfattade själva villfarelsen som meditation.

$\mathrm{Nu}$ är jag en meditationsutövare som är fri från intellektualiserande. 
När vi vill meditera förmörkas meditationen genom själva meditationen.

Men när vi förstår icke-meditationen blir allt till meditation.

Vanliga människor fjättras av själva visdomen.

Men för en yogi omvandlas de fem gifterna och blir till smycken.

Fenomenens natur varken uppstår eller upphör.

Eftersom de lärda inte förstår detta, frågade jag de enfaldiga. Inte heller de förstod, så jag frågade liken på begravningsplatserna.

De förklarade fenomenens natur för mig.

Detta är en dåres meditationserfarenheter i Lachis snöberg. Evam - nedskrivna med ord -

underbart, häpnadsväckande!

Evam! !166 


\section{INSTRUKTIONER TILL HJÄRTESONEN RINCHEN PALSANGPO}

Här följer berättelsen om hur den lyckligt lottade Tashi Rinchen Palsangpo, som hade uppväckt sin inre potential och var Tsangnyöns personliga medhjälpare, blev en hjärteson.

När Rinchen Palsangpo och Tsangnyön vistades i Lachi gav Tsangnyön invigningsritualen som skänker mognad till Rinchen Palsangpo. Därpå lärde han ut de speciella metoderna vilka används när man börjar söka efter det egna sinnet, instruktioner som visar vägen som befriar. Dessutom gav Tsangnyön instruktioner i tummo till Rinchen Palsangpo. Därefter sade han: "Skynda dig nu, det är bråttom, du måste sikta in dig på målet, sinnet!", och så sjöng han denna sång:

Jag bugar mig inför lamorna och vajraḍākinīerna!

Jag ber till den ojämförliga goda rotlaman

som förmedlar det fulländade synsättets

högsta, djupa vägar närhelst någon ber om dessa.

Jag ber också till meditationsgudomligheterna, ḍākinierna och dharmabeskyddarna som skänker allt förverkligande, samt skingrar hinder och ogynnsamma omständigheter.

Den huvudsakliga orsaken till min bön är att jag känner oro över att mitt sinnes gyllene bägare ska angripas av glömskans rost - denna bägare som just nu innehåller den underbara nektar som den strålande lamans tal skänker.

Därför ber jag er, traditionsbärare och ḍākinier, om tillåtelse att nedteckna dessa instruktioner.

Jag ber er också om tillåtelse att, efter att ha hållit instruktionerna hemliga för de som inte är lämpade, lära ut dem till de som är lämpade, i enlighet med lamans instruktioner. 
Vetālī, bröder och systrar hör min bön! ${ }^{167}$

På de vidsträckta slätterna, där saṃsāra och nirvāṇa inte är åtskilda, beträder jag - en son till kagyumästarna den välsignelsebringande traditionens väg.

O du lyckligt lottade, bestig den oföränderliga hängivenhetens häst!

Med den hörda traditionens pil och båge, spänn en armlängd av de mest kärnfulla muntliga instruktionerna!

Efter att ha satt meditationsutövandets häst i galopp, sikta med den självigenkännande visdomens pil på det ofödda sinnet, alltings grund - saṃsāras såväl som nirvāṇas och håll fast vid målet!

Om du inte finner sinnets natur med hjälp av detta. Föreställ dig den uppflammande stavelsen am.

Tänk dig att den kommer nedifrån och att den är klarheten. Föreställ dig den nedfallande stavelsen ham. Tänk dig att den kommer uppifrån och att den är sällheten. Mellan sällheten och klarheten finns sinnet som inte kan förstås - klarhet, tomhet och uppmärksamhet.

Sök efter det!

När du funnit det, håll fast vid målet.

Om du inte finner det, meditera med liv och kraft igen.

Genom denna metod kommer du att se den ursprungliga naturen.

Evam! $!^{168}$

Därefter fortsatte Rinchen Palsangpo sitt sökande efter sinnet genom att meditera. Han presenterade sina meditationserfarenheter för Tsangnyön och beskrev vad sinnet liknar och hur det existerar. Sedan sade han: "Just detta är sinnet! Det finns ingen tvekan om det."

Tsangnyön svarade: "Dessa meditationserfarenheter visar inte att du har funnit sinnet. Meditera igen och sök efter sinnet!" Sedan sjöng han denna sång: 
Namo guru!

Lyssna här, du ädle som önskar se sinnet!

Även om du har mycket bra syn kan du inte se dig själv, precis som ett vasst svärd inte kan skära sig självt.

Du finner inte sinnet genom att söka med sinnet.

Den som finner och den som söker, just detta är sinnet, precis som eld och vatten inte förmår bränna eller väta sig själva.

Trots att sinnets kännetecken har uttryckts på detta sätt, är sinnets natur bortom tankar, beskrivningar och exempel, precis som det är omöjligt för en person som tittar på himlen att med ord beskriva dess gränser, mitt, form och färg.

Med hjälp av kraften som uppstår som ett resultat av meditationen

och genom traditionens välsignelse, framträder med säkerhet visdomens sanna natur inifrån.

Skär igenom saṃsāras och nirvāṇas begreppsbundna tänkande och stanna utan föreställningar, i ett tillstånd bortom kommande och gående.

Evam!

Därefter, genom meditationens kraft, uppstod lyckosamma meditationserfarenheter. Efter att Rinchen Palsangpo presenterat insikten som fastställer synsättet för Tsangnyön, var tiden mogen för instruktionerna som visar sinnets natur.

Tsangnyön sade: "Även om du har haft upplevelser i din meditation har du inte upplevt den yttersta verkligheten."

En morgon fick elden isen att smälta. Denna omständighet gjorde att Tsangnyön frågade: "Varför smälter isen?"

"Den smälter på grund av elden", svarade Rinchen Palsangpo.

Efter detta började solen skina och när en bit av isen hamnade i solen och smälte, frågade Tsangnyön: "Varför smälter den?"

"Den smälter på grund av solens värme", svarade Rinchen Palsangpo.

Sedan pekade Tsangnyön med sina fingrar på ett stycke is som satt 
fast på en klippa och sade: "En dag kommer isen däruppe att smälta. Varför kommer den att smälta?"

"Den kommer att smälta på grund av den annalkande sommaren", svarade Rinchen Palsangpo.

Tsangnyön sade sedan: "Detta var exemplen, nu är det dags för instruktionerna som visar sinnets natur, prostrera!"

Rinchen Palsangpo gjorde som han blivit uppmanad och prostrerade. Därefter, medan Rinchen Palsangpo satt på knä med händerna samman i bön, sjöng Tsangnyön denna sång som visar sinnets natur:

Namo guru!

$\mathrm{Nu}$ ska jag förklara de djupa instruktionerna, vilka förmedlats till mig av kagyulamorna som upprätthåller de tre traditionerna, ${ }^{169}$ samt av andra som upprätthåller rottantrorna. Bevara och utöva dem med ett glädjefyllt sinne!

Vintern får vattnet att frysa.

På samma sätt får uppdelandet i subjekt och objekt sinnets natur - dharmatā, vars natur är bortom begrepp och har en inneboende lyskraft, att frysa.

Elden, värmen och sommaren får isen att smälta. På samma sätt får de muntliga instruktionerna uppdelandet i subjekt och objekt att smälta.

Utan tro, flit och muntliga instruktioner är det ständig vinter.

När du har fått den stora farkostens tantriska instruktioner och inte förvanskat dessa, är elden den flitiga utövningen.

När du fått instruktionerna och inte förvanskat dem, finns värmen även när du inte utövar.

Den fulländade farkostens instruktioner är värme. ${ }^{170}$ Jag ska nu förklara eldens muntliga instruktioner utförligt: Ovanpå en stabil eldstad finns ett kärl. 
Eldstaden representerar avståndstagandet från de tre världarna, medan kärlet representerar tron som är fri från de tre felen. ${ }^{171}$ I detta kärl finns sinnets natur - dharmatā - i ett fruset tillstånd.

De muntliga instruktionerna antänder

subjekt-objekt-uppdelningens ved.

Och när du blåser med ihärdighetens blåsbälg,

om och om igen,

förbrukas veden och kärlets innehåll smälter.

I och med detta framträder sinnets natur helt säkert.

Yogi, utöva på detta sätt!

Evam!

Efter att Tsangnyön sjungit detta sade Rinchen Palsangpo: "Om det nu är så att det som framträder i själva verket är tomhet, och vi helt i onödan uppfattar detta som existens, ge då oss som håller fast vid subjekt och objekt, vi som felaktigt uppfattar det som framträder och tomheten som åtskilda från varandra, en utpekande instruktion."

Som svar på denna förfrågan sjöng Tsangnyön denna sång:

Namo guru!

Sinnets ocean rörs upp av subjekt-objekt-uppdelningens vind. Den oerfarne anser att det är vågorna - det som framträder som ska överges.

Men för de verkligt lärda finns ingen skillnad mellan vågorna och vattnet.

I den yttersta verkligheten finns varken rörelse eller vågor.

När vågorna vållar dig skada, överge vinden!

När du inte skadas är det som vind i samklang med en båt.

Om du så önskar blir en sådan vind till en medhjälpare på vägen.

När du skadas är det metoden att överge som är vinden.

Yogi, det är på det här sättet du ska förstå!

Evaṃ! 
TSANGNYÖN HERUKAS SÅNGER

Så sjöng Tsangnyön och Rinchen Palsangpo blev en hjärteson som hade insikten av att ha känt igen sitt naturliga tillstånd. 
INSTRUKTIONER TILL PRINS SAMDRUB DE

Efter detta kommer ett avsnitt som innehåller de fulländade sångerna med muntliga instruktioner till den mäktige konungen av Mangyul och hans söner. Tsangnyön sjöng dessa sånger i samband med resan till Kailash och de sex forten i Mangyul, en resa som mästaren utförde tillsammans med sina lärjungar.

Herre, jag bugar mig inför laman! Må det dyrbara uppvaknandet uppstå i sinnet!

Dessa fulländade sånger är strålande i sin lyckosamhet. Sångerna klargör insikten om den yttersta verkligheten. De är den högsta vägen vilken befriar de lyckligt lottade, när de hör dem. Sångerna är spegeln som klart återspeglar grunden, vägen och resultatet. De är det outtömliga havet, den slutgiltiga befrielsens väg: synsättet, meditationen, handlingen och resultatet. De är essensen av alla vajrayānas djupa vägar. De förstärker insikten hos dem som har erfarenheter av meditation. Sångerna, i förening med yttre omständigheter, ger verkningsfull näring åt dem som har en kraftfull disciplin. Till och med alla de med dåliga förutsättningar leds, genom att endast lyssna till sångerna, bortom objektsuppfattandet. Sångerna är nektar för de lyckligt lottade individer som har tro och flit. Okonstlad tro och hängivenhet uppstår bara genom att höra sångerna. Sångerna har förmågan att också rena alla dem som samlat negativa handlingar och skymmande slöjor sedan begynnelselös tid i saṃsāra. De är den oöverträffade medicin som förvandlar de fem gifterna till de fem visdomarna, den stora eld som förbränner jaguppfattningens ved. De är generalen som besegrar fienden - det dualistiska klängandet. Sångerna är det heliga skepp som befriar varelserna från saṃsāras ocean.

Tsangnyön är alla de tre tidernas buddhors innersta väsen, en tillflykt för alla varelser i de tre sfärerna och en ledare för varelserna i de tre världarna. Han är laman som manifesterar de tre kropparna hos alla dem som upprätthåller kagyulärans segerbaner. Han är den utövande traditionens stora skattkista. Genom att han öppnat halsens glädjekanal flödar ett hav av vajrasånger fram, och genom att han 
upplöst centralkanalens knutar har det dualistiska fastklängandets förvirring upphört. ${ }^{172}$ Eftersom han uppnått kontroll över de fyra elementens vind bemästrar han alla företeelser, det som uppstår och det som existerar, saṃsāra och nirvāṇa. Han har fulländat den klart framträdande meningen som är fri från föreställningar - det obegränsade mahāmudrā. Efter att ha lämnat alla rädslor, alla förhoppningar och all oro bakom sig, för han alla kännande varelser utan undantag till mognad och befrielse. Han gör detta med hjälp av kraftfull disciplin.

För oss som har förmågan att se hans goda egenskaper är han fadersiddhornas konung. Hans namn är vida känt som Tsangpa Heruka Sangye Gyaltsen, eller som "Han som har benornament".

Tsangnyön mottog kompletta instruktioner från den ojämförlige Shara Rabjampa. När tiden var kommen för att bege sig till det höga och strålande Tsari, den heliga platsen i söder, sade den enastående Shara Rabjampa, mästaren: "Hej, Dharmas berömmelse från Tsang! ${ }^{173}$ Se inte till detta liv! Vänd ryggen åt de åtta världsliga angelägenheterna och res utövandets segerbaner på kagyutraditionens heliga platser: Tsari-Tsagong, Lachi-Chuwar, Kailash och så vidare! Utöva hela ditt liv!"

I enlighet med dessa ord utövade Tsangnyön i Tsari, i Lachi-Chuwar, och på andra platser. Därefter, när han var på väg tillbaka från Kailash, besökte han heliga platser såsom de sex forten. Vid detta tillfälle fanns det några argsinta dörrvakter som vaktade de inre och yttre dörrarna till kung Namgyel Des palats. Denne kung hade stigit ner från de strålande gudarna. ${ }^{174}$ Han var herren över Tibets snöhöljda rike - Trädportarnas land. Namgyel De var en emanation av den ädle Lokeśvara och härstammade från dharmakungen Songtsen Gampo. Han var kung i Mangyul Gungtang.

Vakterna paralyserades av Tsangnyöns kraftfulla disciplin, och han gick obehindrat in i kungens palats. Kungen och dennes följeslagare blev chockade och stirrade på honom. Men de förstod att Tsangnyön var en yogi och fylldes med hängivenhet och tro. Kungen och dennes äldste son Norbu De bad honom enträget stanna och tog hand om honom på ett utmärkt sätt.

Efter att ha blivit mycket väl omhändertagna stannade den vördade mästaren med sina lärjungar i en eremitboning vid namn Fotavtryck- 
ets grotta. Denna avlägsna plats hade använts av vördade Mila när han utövade meditation. ${ }^{175}$ Mila från Mangyul Gungtang föddes i Kyanga Tsai Korön och han är än i dag kagyulärans grundstomme. På denna plats utövade Tsangnyön och hans följe för allas väl och med full koncentration.

Vid den tidpunkten tänkte kung Namgyel Des andre son, prins Samdrub De, dessa tankar: "Denne yogi är kunnig i skrifterna och bra på att argumentera. Han har utstrålning och har uppnått enastående mirakulösa förmågor. Han är någon som förefaller ha kraften att kontrollera företeelserna i världen. Men han är också någon vars vårdslösa handlingarär fler än tanken kan omfatta. Eftersom jag inte känner honom och det dessutom är mycket viktigt att undersöka alla yogier i denna dåliga och degenererade tidsålder, för att se om de är bra eller dåliga, ska jag granska honom lite grann.”

Efter att ha tänkt detta visade prinsen ingen respekt eller vördnad över huvud taget. Han var fullständigt likgiltig inför Tsangnyön.

Den vördade helige laman tänkte då för sig själv: "Har jag en karmisk förbindelse med denne prins eller inte? Jag måste undersöka hur stark tillit prinsen har."176

En dag gick han fram till prinsen och sade: "O, härskare! Skapa en bra förutsättning för oss yogier genom att ge oss ett stöd i form av mat och förnödenheter!”

Som reaktion på denna förfrågan tänkte prinsen: "De vanliga outbildade människorna och yogierna som vandrar runt i världen samt vårt lands lärda munkar som är kunniga i sūtra och tantra är alla överens om att han är en bra yogi. Eftersom både min far konungen och min äldre broder respekterar och betjänar denne yogi så har han inga problem med sitt livsuppehälle. Han kommer att byta ut det han får mot något annat och omvandla det han burit med sig till rikedomar. Eller så är det också möjligt att han prövar mig. Jag måste använda mig av de hårda ordens vapen för att avgöra om han är en bra eller en dålig yogi.”

Sedan lovprisade och bad kungen till Milarepa, och så yttrade han dessa nedsättande ord om mästaren, den ojämförlige, yogiernas herre (Tsangnyön): 
Utövande asketism drack du endast vatten och därmed gick du till asketismens yttersta gräns. Din kropp flammade av sällhetens värme, och du bar endast några bomullskläder på din kropp. Med insikten i alltings yttersta likvärdighet dväljdes du ständigt i klarheten. Jag bugar mig respektfullt inför dina fötter, Milarepa!

Men vad dig beträffar så är du en dåre och tiggare. Oförmögen att stå ut med prövningar är du slö och likgiltig.

Du har ett omoget sinne och du är en hycklare.

Utan en tanke på den annalkande döden smutsar du ner Milas mycket heliga plats med en mängd olika orenheter.

$\mathrm{O}$, store mästare (Milarepa), ha medkänsla med denne vanhelgare!

Efter att ha sagt detta funderade prinsen över vad Tsangnyön skulle säga, och för att svara prinsen sjöng fadersiddhan - han som tillintetgör villfarelserna - denna storslagna sång som vederlägger felaktig argumentation och visar hur tillkortakommanden i själva verket kan vara goda egenskaper. Sången liknar nektarelixiret som botar de fem gifternas sjukdom eller den önskeuppfyllande juvelen som utan ansträngning uppfyller alla tillfälliga och slutgiltiga önskningar och begär.

Jag bugar mig inför kagyulamorna!

Du förstod skrifterna och befriade andra.

Du såg meningen bortom orden och befriade dig själv.

Du fulländade det som gagnade dig själv och andra. ${ }^{177}$

Du är de lärdas kronjuvel.

Jag bugar inför dina fötter, ojämförbare Rabjam Chöje!

Hör upp, du son av gudarna!

Detta svar som prinsen gav mig är verkligt meningslöst och löjeväckande 
i sin oklarhet beträffande om prinsen ska ge stöd eller inte ge stöd i form av mat och dryck.

Lyssna ordentligt huruvida jag, en galen yogi som vandrar runt i världen, har förstått dig rätt!

Efter att prinsen lovprisat den store bomullsklädde (Milarepa), uttalade ni er på följande sätt angående min karaktär:

"Du är en dåre och tiggare.

Oförmögen att stå ut med prövningar är du slö och likgiltig.

Du har ett omoget sinne och du är en hycklare.

Utan en tanke på den annalkande döden smutsar du ner Milas mycket heliga plats med en mängd olika orenheter.

O, store mästare (Milarepa), ha medkänsla med denne vanhelgare!"

Denna bön är till stor hjälp.

Eftersom svar uppstår också när man ropar mot en klippa, ska även jag sjunga en spontan sång för att förklara meningen med kungens ord.

Låt dig inte störas av annat! Lystra hitåt!

Utan att förlora uppmärksamheten, lyssna en stund!

Denna person som kallas för "jag" räknar jag inte som framstående.

Men min traditionslinje är speciellt framstående.

Från den store Vajradhara och fram till Rabjam Chöje har den endast upprätthållits av individer som är emanationer av den uppvaknade. Därför är den särskilt underbar.

Min traditionslinje är full av dårar och tiggare. Jag är son till en fader från en utomordentlig tradition. 
Jag är upprätthållaren av dårarnas traditionslinje. Därför handlar alla biografierna om olika dårar.

När jag sjunger om hur rätt prinsen har, ler de uppvaknade kunskapsbärarna och deras följe förtjust och förundrat.

Slutligen börjar de skratta åt att det finns en sådan underbar form av galenskap.

Synsättet

- föreningen, bortom begränsningar har gjort mig galen.

Meditationen

- klarhet, tomhet, bortom fastklängande har gjort mig galen.

Uppförandet

- att trampa ner rädslor har gjort mig galen.

Grunden

- bortom alla överdrifter har gjort mig galen.

Vägen

- att avstå från negativa handlingar och utöva goda handlingar har gjort mig galen.

Resultatet

- att ha känt igen min egen verkliga natur har gjort mig galen.

Medan galenskapen finns i själva grunden, har också demoner gjort mig galen.

De manliga demonerna

- kagyutraditionens välsignelse har trängt in i mig. 
Jag har uppnått de kvinnliga demonernas

- dākinīernas - aktivitet.

Förnöjsamhetens demon har angripit mitt hjärta.

De kvinnliga demonernas visdom stöttar roten till mitt medvetande.

Pådriven av erfarenheterna och insikterna som lyser fram, har jag plötsligt stigit upp ur begärets och fastklängandets säng.

Efter att ha kastat av mig kläderna

- de två slöjornas vanetendenser springer den obefläckade uppmärksamheten runt naken.

Skamlöst vilar de sex sinnena i sin natur.

Jag har spräckt de åtta världsliga angelägenheternas lergods och kastat mig ut i avgrunden, där det varken finns hög eller låg.

Jag har krossat de fem gifternas huvud - orenheterna i sinnet och glömt bort saṃsāras uppdelning i subjekt och objekt.

Om denna typ av galenskap skulle uppstå, vore det bra om också kungen själv blev galen.

Därefter kallade kungen mig för tiggare, vilket också är sant.

Djupt inom mig, i tron på grundmedvetandet, fanns en hunger efter sällhet och metod, samt en törst efter vishet och tomhet.

Där uppstod en intensiv smärta av sorg och avståndstagande.

Sökande mat och dryck i lamans instruktioner intog jag djupmeditationen som är fri från intellektualiserande som föda.

Genom detta skingrades hungerns smärta.

Jag drack från medkänslans svalkande flod, och genom detta skingrades törstens lidande.

Både mätt och belåten sov jag gott. 
Därefter njöt jag återigen otvunget av

denna mat och dryck utan att bli däst.

Eftersom traditionens välsignelse brinner i lyssnandets, reflektionens och meditationens inre, så kan också mat offrad av hängivenhet, som liknar järnblock, ${ }^{178}$ med säkerhet smältas om jag skulle äta den.

Alla som gett gåvor till mig har vunnit på detta.

Om den här sortens tiggande skulle uppstå, det högsta felfria tiggandet, så vore det bra om också prinsen själv ägnade sig åt det.

Därefter sade prinsen att jag inte klarar av prövningar, vilket är sant.

Jag står inte ut med den stora passionens och kärlekens prövningar

hos de som för att föda en familj till vilken de känner begär bortser från allt lidande:

hettan, kölden, tröttheten och så vidare.

Detta leder endast till de hungriga andarnas hunger och törst.

Jag står inte heller ut med

de ryktbara djärva männens prövningar.

De som för att besegra sina hatade fiender

varken bryr sig om kropp eller liv.

För att fylla sina magar utför de begravningsritualer och ber till världsliga gudar.

Efter att ha kastat bort sina friheter och möjligheter ${ }^{179}$ hamnar de i helvetenas hetta och köld.

Jag står inte heller ut med de prövningar som är förknippade med dem som inte kan skilja mellan rent och orent. Även om de kommer i kontakt med Buddhas lära förverkligar dessa personer, hårt fastbundna som de är vid okunnighetens säng, varken högre återfödelse eller befrielse. 
Likt hundar och grisar uppför de sig vårdslöst. Inriktade på sådant som har med detta liv och de fem gifterna att göra, förverkligar sådana personer utan undantag lidande.

Utifrån en annan synvinkel kan orsaken förklaras på följande sätt:

Om sköldpaddor inte har något hår, vem ska då klä sig i kläder tillverkade från dem?

Om ofruktsamma kvinnor inte har några barn, vem ska då leda dem till deras döda barns kropp?

Om himlen saknar kanter och mitt, vem kan då mäta dess storlek?

Det är svårt att skapa det naturliga tillståndet.

Om inte ens de segerrika vet hur man skapar det, hur skulle en vanlig människa kunna göra det?

Om en lära om det svåra saknas i traditionen, hur kan jag då vara lämpad att följa den?

Om prövningar uppfattas som något som ska utföras, hur kan det då vara min, dårens, tradition?

Detta var en sång om den verkliga meningen.

Den är sprungen ur min oförmåga att stå ut med prövningar.

Om det handlar om en oförmåga att stå ut med prövningar av detta slag,

så är de segerrikas intentioner fulländade.

Det vore bra om kungen själv också hade den.

Därefter sade kungen att jag är slö och likgiltig, vilket också är sant.

Jag har insett att alla varelser är som min mor och far.

Därför gör jag ingen skillnad mellan närstående och fiende, utan förblir i ett tillstånd av opartiskhet. 
Orsak och verkan är rena från begynnelsen.

Därför skiljer jag inte mellan handlingar som ska utföras och handlingar som inte ska utföras, utan förblir i ett tillstånd av jämnmod.

Tillvarons natur framträder inifrån.

Därför kan varken lycka eller lidande rubba mitt inre lugn.

Allting har ytterst samma smak.

Därför förblir jag opåverkad av både sinnets stillhet och sinnets rörelse.

Jag mediterar på föreningen av uppbyggandets

och fullbordandets meditationsfaser.

Därför förblir jag opåverkad av både födelse och död.

Jag äter djupmeditationen som mat.

Därför förblir jag opåverkad av både hunger och törst.

Jag har stoppat fastklängandet i mitt inre.

Därför förblir jag opåverkad av både framgång och misslyckande.

Saṃsāra och nirvāṇa är synonymer.

Därför förblir jag opåverkad av både beröm och klander.

De som tillhör min tradition har allt detta jämnmod.

Jag själv har det endast i begränsad omfattning.

Men jag tänker att även jag fortfarande måste utöva

det helt fulländade jämnmodet i sin helhet.

Det vore bra om även kungen kunde utöva på samma sätt.

Därefter sade kungen att jag har ett omoget sinne, vilket också är sant.

Jag har vattnat det opartiska grundmedvetandets åker med fixerat fastklängande.

Och efter att ha sått sinnets orenheters frö, plogade jag med plogoxarna som delar upp i subjekt och objekt. Efter att ha jämnat ut plogfårorna med högmodets harv, var skotten på väg att komma upp. 
Men just när de fem gifterna höll på att slå rot i mitt sinne, vände floden av mina karmiska meriter.

Och min traditions välsignelser forsade in i åkerns bevattningskanaler.

Detta kombinerades med trons, hängivenhetens och medkänslans torka.

Därför kunde de fem gifterna inte mogna i mitt sinne.

Efter detta kom några enstaka

dåliga skott upp här och var, men begärets och fastklängandets gödning saknades.

Under lång tid brändes skotten, de torkade ut i den varma solen - traditionens medkänsla.

Därför kunde inte de dåliga skotten mogna i sinnet.

Genom hängivenhetens vind och den flitiga utövningen av lamans instruktioner skingrades de fem gifternas moln av sig själva. Rimfrosten, som uppstår och befrias av sig själv, upplöstes.

Det som var kvar när det mesta hade förbränts, förintades av dharmakāyas frost.

Därför kunde de inte mogna i sinnet.

Genom bönen som leder till övertygelse har välsignelsen nått mitt sinne.

Den oföränderliga medkänslans moln samlades på himlen som är utan tal, tanke och uttryck.

De fem visdomarnas hagel föll ner, och de återstående frostpartiklarna krossades till stoft.

Därför kunde de inte mogna i sinnet.

Eftersom mina hinder uppstår på detta sätt, försök se om det finns tid för sinnets orenheter och de fem gifterna att mogna i mitt sinne!

Och om de fem gifterna mognar i sinnet, kastas vi in i de fem saṃsāriska tillstånden. Och där finns ingen möjlighet till lycka. 
För att undvika att något dåligt mognar i sinnet, ber jag att uppnå lyckan.

Och inte födas i de fem samsāriska tillstånden, där vi hjälplöst upplever lidande.

Det är på detta sätt jag är omogen.

Det vore bra om också kungen vore omogen på detta sätt.

Därefter sade kungen att jag är en hycklare, vilket också är sant.

Även om jag inte behöver hyckla,

låtsas jag utföra de tio förtjänstfulla handlingarna när varelser som utför de icke-förtjänstfulla handlingarna ser mig.

När de som klänger fast vid saṃsāras företeelser ser mig, låtsas jag uppnå befrielse. ${ }^{180}$

När de som är fjättrade vid de åtta världsliga angelägenheterna ser mig,

låtsas jag vara en dåre.

När de varelser som har felaktiga uppfattningar ser mig, låtsas jag vara en galen gammal bluffmakare.

När de som behöver tränas på olika sätt ser mig, låtsas jag i enlighet med vars och ens behov.

Om den här sortens hyckleri kunde uppstå, vore det bra om också kungen själv blev en hycklare.

Därefter sade kungen att jag inte tänker på döden, vilket också är sant.

Tanken på att hängivenheten

till laman och de tre juvelerna

skulle dö, finns inte.

Tanken på att den rena synen

gentemot mina vajrabröder och -systrar

skulle dö, finns inte.

Tanken på att kärleken

till de sex kategorierna av varelser, mina goda föräldrar, skulle dö, finns inte. 
Tanken på att medkänslan med de tre lägre världarnas varelser skulle dö, finns inte.

Tanken på att opartiskheten inför den begynnelselösa identiteten av saṃsāra och nirvāṇa skulle dö, finns inte.

Tanken på att glädjen över de som har tro och flit skulle dö, finns inte. ${ }^{181}$

Tanken på att stillheten inför alla företeelsers naturliga enkelhet skulle dö, finns inte.

Tanken på att insikten i kunskapen som kommer genom att jag känner igen min egen natur

skulle dö, finns inte.

Tanken på att uppbyggandet av min egen kropp som spontant närvarande i gudomens form skulle dö, finns inte.

Tanken på att fullbordandet av sinnets innersta väsen - naturlig klarhet skulle dö, finns inte.

Tanken på att föreningen

av fader och moder - det medfödda framträdandet och tomheten -

skulle dö, finns inte.

Tanken på att glädjen $i$ att vandra runt bland bergen och i vildmarken skulle dö, finns inte.

Tanken på att fliten i utövningen av studier, reflektion och meditation skulle dö, finns inte. 
Återigen sjunger jag en sång om den verkliga meningen.

Eftersom alla ting ursprungligen inte uppstår,

hur kan detta som inte har fötts dö?

Eftersom inte heller jag har blivit född genom en födelse så finns inte tanken på att sinnet kommer att dö.

Därför har kungen rätt.

Om det handlar om att inte tänka på döden på detta sätt, så vore det bra om även kungen själv inte tänkte på döden.

Därefter sade kungen att jag vanhelgar Shepa Dorjes heliga plats. ${ }^{182}$

Återigen har kungen rätt.

Vanhelgandet uppstår på grund av föroreningar.

Mina föroreningar har följande grund:

I och med att jag avrättade omedvetenheten som föddes samtidigt som medvetenheten, uppstod föroreningen av att ha mördat en anhörig.

I och med att min moder och fader, uppdelningen i subjekt och objekt och dess hopp och rädslor dog, uppstod lidande, glädje och sällhet

- känslornas förorening.

I och med att jag mötte den sköna kvinnan, som naturligt inneboende i mig själv, uppstod en oskiljaktig sexuell förening

- oanständighetens förorening.

I och med att medvetenhetens barn

föddes i sinnet, uppstod jaglöshetens insikt

- otuktens förorening.

I och med att min livskamrat, den befästa uppdelningen i subjekt och objekt dog, uppstod den stora självbefrielsen

- änklingsståndets förorening. 
I och med att jag inte ens förmår tala om sådant som de tio icke-förtjänstfulla handlingarna, uppstod förverkligandet av deras motsats - osämjans förorening.

I och med att jag smittades av epidemin som genomtränger allt, dharmakāya, upprördes jag av stillheten och insikten

- sjukdomens förorening.

Efter att jag dödat de fem gifterna och ätit upp deras kött och blod rått, uppstod blodets förorening. ${ }^{183}$

Efter att jag tog livet av fienden, egoklängandet, uppstod önskan och tillämpningen ${ }^{184}$ - blodspengarnas förorening. ${ }^{185}$

Genom att koka smältande sällhet med hjälp av tummo, brann den lycksaliga värmen - eldstadens förorening.

Genom kunskapens och vishetens stora eld uppstod brännandets förorening och de vanemässiga tendenserna brann upp.

Även om det vore nödvändigt att vanhelga denna heliga plats med dessa olika sorters föroreningar, så har just dessa föroreningar redan verkat. Mila, solen har redan besudlat den.

Därför behöver inte den galna stjärnan besudla den. Jag själv hoppas också bli befläckad av dessa föroreningar. Jag delar dessa så kallade föroreningars förtjänst så att såväl det rena yttre stödet (världen) och de som är beroende av det (de kännande varelserna), de som ser fel i mina anfäders dygder, fastän dessa är utan föroreningar, ska betvingas och besudlas av mina så kallade föroreningar. 
Må varelserna därigenom uppnå mognad och befrielse, och må alla buddhaländer renas!

Dyrbara kagyumästare, skänk er välsignelse så att jag uppnår ännu stadigare grund för dessa föroreningar!

Om det rör sig om ett vanhelgande av detta slag, så vore det bra om även kungen själv kunde utföra det. Det är i full överensstämmelse med kagyumästarnas livshistorier!

Segern är strålande!

Denna sång är i full överensstämmelse med den muntliga överföringens och insiktens tradition och alla dess mästares livshistorier, från den store buddhan Vajradhara och framåt!

Segern är strålande! $!^{186}$

Sången fick prinsen att känna tro och hängivenhet. Han sade: "När jag förolämpade läraren, yogin, så visade han i gengäld sina enastående kvaliteter. Vilken oerhörd godhet, så underbart!"

Läraren, mästaren, sade då: "Utöver det jag yttrat i sången kan följande nämnas om kunskapen: Allt det som framstår som ett felaktigt fasthållande vid tillvarons kretslopp fullkomnas spontant som goda egenskaper för yogin, från första början och alltid. Yogin har inte heller något behov av det som uppstår.

Beträffande okunskapen är det på följande sätt: Till och med den uppvaknades alla goda egenskaper framstår som fel för de vanliga människorna som inte tränat sinnet på buddhismens väg, samt för dem som har ett felaktigt synsätt. Den som är fast i begäret gör, genom sitt begär, begäret till ett hinder. ${ }^{187}$

För att uttrycka hela meningen i ett nötskal: För dem som inte förstår företeelsernas verkliga natur uppstår tillvarons kretslopp. Men om man förstår, är företeelserna i själva verket fridens (nirvāṇas) stora 
sällhet, från allra första början. Detta illustreras också av liknelsen som säger att det i himlen saknas behov av himmel.”

Dessa ord gjorde prinsen än mer hängiven. Han sade: "Du nämnde att du behövde stöd i form av mat och förnödenheter och detta ska jag sannerligen ge dig, o lärare och yogi. Och efter det att jag gett mycket kött, smör, korn och så vidare - och också läraren och lärjungarna mottagit dessa gåvor - ber jag dig att i gengäld utföra en offerritual till dharmabeskyddarna och väktarna. Därtill ber jag dig om att be goda önskeböner för mig, din välgörare, samt ge mig en beskyddande amulett. Dessutom skulle jag vilja att du utför en drömtolkning."

Mästaren, den mäktige yogin svarade med denna sång:

Jag bugar inför mästarens - den högt skattade konungens fötter! ${ }^{188}$

Nåväl, hängivne prins, gudomlige son, härskare Samdrub De!

Lyssna ännu en gång till yogins sång!

Att ge de heliga substanserna

som är förbundna med ḍākinīerna och dharmabeskyddarna: välsignat vin, helgat kött och smör - detta är utmärkt och till nytta för både dig själv och andra.

I allmänhet genomsyras alla varelser av buddhanaturen.

I synnerhet - vad beträffar kroppen hos en yogi

som har beträtt den högsta vägen är den utvändigt de gudomliga gestalternas palats.

Invändigt finns där de tre subtila kanalerna (nādì), de fyra cakra, de gudomliga formerna, samt den röda och vita bodhicitta.

De fyra kategorierna av tantragudomligheter är utmärkta objekt att offra till.

Viraer och ḍākinīer är metod och visdom - utmärkta objekt att offra en rituell fest till.

Dharmabeskyddarna och väktarna är de som utför aktiviteterna - utmärkta objekt att tillägna tacksägelseritualer. 
Den fyrfaldiga församlingen (sangha) är något som ska vördas - de är utmärkta objekt för högaktning.

Alla de sex kategorierna av varelser som föds på fyra olika sätt ${ }^{189}$ är utmärkta objekt att ge allmosor till.

Därför är även en galen yogis

alla upplevelser av sinnesnjutning, mat och dryck

ett givande av torma och ett offrande av rituella fester.

Oavsett om han går, står eller ligger,

är allt som den gör, vilken har fulländat den stora farkostens

högsta väg,

att likställa med att gå runt heliga objekt

eller buga sig i vördnad för dem. ${ }^{190}$

Allt han eller hon säger,

oavsett om det är sanning eller lögn,

ovänliga eller vänliga ord,

är hemliga mantror.

Allt som uppstår i hans eller hennes sinne, oavsett om det är goda eller dåliga tankar, är djupmeditation.

Därför kommer ingenting av det du ger att vara bortkastat.

Jag kommer att använda det på ett bra sätt och tillägna nyttan för din nuvarande och slutgiltiga lycka.

Därefter sade du att du behöver beskydd.

Beträffande denna önskan,

ska jag skänka dig beskydd till varje pris.

Om prinsens kropp behöver beskydd, strunta i kroppen och sluta att hålla den kär.

Om ditt tal behöver beskydd, sluta prata och recitera Tathāgatas essens. ${ }^{191}$

Om ditt sinne behöver beskydd, vila i ett tillstånd som är utan aktivitet och bortom begrepp. 
Om ditt följe behöver beskydd, se dina fel och avstå från begär.

Om din rikedom behöver beskydd, sluta samla på hög och ge gåvor.

I korthet, vad än du önskar beskydda, om sinnet ger upp begär och bundenhet, kommer allt ofördelaktigt att framstå som gynnsamt.

Detta är det främsta av allt beskydd.

Aldrig i denna värld går det att finna något beskydd som är mer omfattande än detta.

Därefter, som svar till din uppmaning om att uppfylla dharmabeskyddarnas och väktarnas önskningar har jag följande att säga:

Även om jag uppfyller de heliga löftena gentemot beskyddarna, genom att offra de yttre, inre, hemliga och slutgiltiga rituella gåvorna,

så skulle deras upplysta aktivitet ta livet, ifrån mig om jag bryter mot dharma.

En person som handlar enligt dharma fullbordar däremot alla de gynnsamma omständigheterna, även om han eller hon inte har offrat till beskyddarna.

Sådana är beskyddarnas uppriktiga handlingar och beskydd.

Eftersom vad som än uppstår när vi drömmer till sitt innersta väsen är dharmatā, är allt det som uppstår helt och hållet perfekt.

Om du samtycker till denna anspråkslösa sång som uppstod från mina erfarenheter, kan du omsätta den i handling. Den är i överensstämmelse med kagyumästarnas livshistorier.

Om du inte samtycker, kan du låta den vara.

Den uppstod spontant hos en fördomsfri dåre. 
Må denna anspråkslösa sång med alldaglig betydelse få Buddhas lära att spridas!

Må den få de kännande varelserna att bli glada och lyckliga! Jag offrar melodin till de tre juvelerna.

Njut av ljudet, skaror av ḍakinīer!

Skingra störande omständigheter, Tseringma!

Nå fram till lyckosamhet, alla kännande varelser!

Evam!

Denna sång gjorde att prinsen och fadern blev hängivna och uppfyllda av tro.

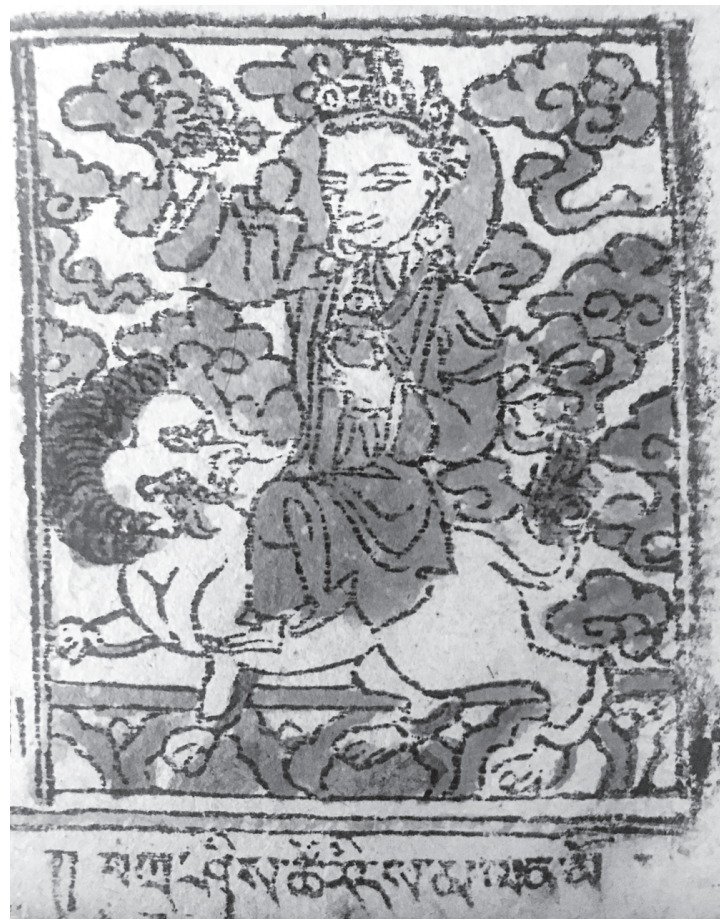

Bild 11. Tseringma (gTsang smyon he ru ka, gTsang pa he ru ka'i mgur'bum: 28a). 


\section{DEN STORSLAGNA SÅNGEN - JAGLÖSHETENS LEJON, RYTANDET SOM UTTRYCKER DEN YTTERSTA MENINGEN}

Medan de mäktiga kungligheterna - fadern och sönerna - erbjöd sig att stödja Tsangnyöns uppehälle, undervisade han många lyckligt lottade individer på denna plats genom att sätta den stora farkostens hjul i rörelse. Några av områdets invånare tillhörde dock śrāvaka- och pratyekabuddhornas skara och kunde inte ta till sig den omedelbart fulländade och slutgiltiga stora farkostens läror. De talade nedsättande om Tsangnyön på många olika sätt. Bland annat sade de: "I allmänhet är det inte lämpligt att utöva den hemliga mantrafarkosten i dessa tider, och det är inte heller lämpligt att meditera på det sätt som Tsangnyön förespråkar. I synnerhet har inte Buddha undervisat om det synsätt, den meditation och det handlingssätt som Tsangnyön talar om.”

Tsangnyön tillkallade några av de personer som följde de lägre farkosterna och bemötte deras felaktiga synsätt både med hjälp av övertygande argument hämtade från de buddhistiska skrifterna och genom logiska resonemang. Därefter sjöng han den storslagna sången som uttrycker den yttersta meningen - Jaglöshetens lejon, vars rytande skrämmer och underkuvar de sköra hjortdjuren som följer den lägre farkosten.

\section{Namo guru!}

I eremitboningen Fotavtryckets grotta,

har jag, en galen yogi som vandrar runt i världen, upplevelser medan jag sover.

Jag ska nu förklara lamornas heliga lära

- glädje, lycka och förening.

Jag ska förklara denna lära med hjälp av den som är förträfflig, lärd och rättfärdig i sitt synsätt, i sin meditation och i sitt handlingssätt. 
Den förträfflige laman, liket på begravningsplatsen, åskådliggör synsättet, dharmatā, oändligt som rymden. Han visar oss den djupa heliga läran, vår natur. Insikten som är bortom ytterligheter och intellektualiserande glädjer dåren.

Den lärde laman, den stumme, bortom tal, åskådliggör meditationen med månens spegelbild i vattnet. Han förklarar erfarenheterna av den heliga dharma, våra drömmar.

Upplevelsen av klarhet och tomhet, bortom ord, gör dåren lycklig.

Den rättfärdige laman, den obekymrade dåren, åskådliggör handlingssättet, likt barnets, vars sex sinnen är fria och okonstlade.

Han avslöjar vår skenhelighet, vilket är den heliga dharmas uppgift.

Upprätthållandet av ett okonstlat och avslappnat uppförande förenas i yogan.

Denna anspråkslösa sång om glädje, lycka och förening riktar sig till de lyckligt lottade och till de olycksaliga, de som utvecklas omedelbart och de som utvecklas gradvis, personer som liknar påfågeln respektive giftormen. I de olycksaliga finns gift på samma sätt som dödligt gift finns i vissa djur.

De lyckligt lottade följer den stora farkosten som leder till omedelbart förverkligande.

De klarar av att äta allt, precis som påfågeln.

Eftersom ätandet ökar deras strålglans, kraft och goda egenskaper,

införlivar de i sin utövning sådant som andra anser vara ett dödligt gift

och tar avstånd från.

De olycksaliga, som följer den lägre farkosten, śrāvakaerna och pratyekabuddhorna, utvecklas gradvis. De tar avstånd från allt, precis som giftormen. 
Endast förnimmelsen av något orent får dem att rygga tillbaka på grund av sin rädsla.

Minsta lilla ljud gör dem skräckslagna, och de talar illa om andra.

Genom medkänslans välsignelse i den stora farkosten, och genom kraften i mina, yogins, rena upphöjda önskningar, må alla varelser gradvis beträda den stora farkostens väg! Och må de snabbt uppnå det allvetande, fulländade uppvaknandet!

Evam! 


\section{INSTRUKTIONER TILL SHENGOM DORJE NYINGPO}

\section{- INTRODUKTION TILL DEN DJUPA MENINGEN}

När sedan vintern var i antågande bjöd den mäktige konungen, fadern, och hans söner den dyrbare mästaren och hans lärjungar till Kyirong.

När Tsangnyön och hans lärjungar vistades i mahāsiddha Urgyenpas heliga utövningsplats, Kökardrag, blev en pönpo vid namn Dorje Nyingpo och dennes lärjunge, bägge från östra Tibet, Tsangnyöns lärjungar. ${ }^{192}$ Efter att Dorje Nyingpo skickat sin lärjunge till Nepal bad han Tsangnyön om dharmaundervisning. Tsangnyön undervisade Dorje Nyingpo om hur man söker efter sinnet, och när tiden var mogen sjöng han denna sång som visar sinnets natur:

\section{Namo guru!}

Lyssna! Dorje Nyingpo, du som söker efter sinnet.

Eftersom sinnet är just den som söker, hur kan du finna det genom att söka?

Även det vassaste svärd kan inte skära sig självt.

Inte ens med den skarpaste syn

kan du se dig själv.

Sök inte efter vatten när du är törstig och håller på att drunkna!

Trötta inte ut dig själv genom att försöka knyta upp himlens knutar!

Sörj inte över en ofruktsam kvinnas döda barn!

Att göra detta vore som att söka

efter sinnet som du aldrig kan tappa bort.

Den fulländade buddhan är ingenting annat än sinnet.

Därför, lita till dig själv

och lyssna till denna sång om det egna sinnets natur.

I begynnelsen är det egna sinnet, det ofödda grundmedvetandet, inte orsakat av någonting; det är utan orsak. ${ }^{193}$ Slutligen är det utan begränsningar och saknar essens. 
Sinnet är skilt både från tillvarons kretslopp och friden, där finns varken partiskhet, centrum eller periferi.

Eftersom sinnet inte är någonting konkret har det inga specifika kännetecken, ej heller färg. Sinnet är ingen enhet, utan uppenbarar sig på allehanda sätt.

Fastän sinnet är bortom ord uttrycks dess natur med ord.

När du ihärdigt söker efter det förblir det dolt, men när du vilar i avspändhet visar det sitt ansikte.

Om du vill ha kunskap om sinnet så sjunger jag ännu en sång. Evam!

När han lyssnat till denna sång förstod pönpon sinnets natur, och han blev en hängiven dharmautövare. 
INSTRUKTIONER TILL FADERN, KONUNGEN (NAMGYEL DE) - EN UPPFORDRAN SOM AVSLÖJAR TILLKORTAKOMMANDEN

Kort därefter kom pönpon Dorje Nyingpos lärjunge tillbaka från resan till Svayambhū och hade med sig en dyrbar rituell vas från Nepal. Vid en vägkorsning mötte han kungen, prinsarna och deras följeslagare. ${ }^{194}$ Kungen och hans följeslagare ofredade lärjungen, förstörde hans tillhörigheter och stal hans rituella vas.

När Tsangnyön fick höra talas om vad som skett sade han: "Kungen och hans följeslagare måste återlämna vasen till Dorje Nyingpos lärjunge.” Därpå sökte Tsangnyön upp fader konungen och sjöng denna uppfordrande sång som avslöjar tillkortakommanden:

Namo guru!

$\mathrm{O}$, du lärde, store konung, som härstammar från dharmakungarna, vilka steg ner från det klara ljusets gudomligheter, lyssna till en galen yogis sång!

Jag, yogin, tappade koncentrationen och föll i sömn i min ensliga boning. Jag vet inte om det jag hörde och såg i drömmen är sant eller inte.

Dessa ord beskriver vad jag upplevde:

Snöbergets vita lejon användes som en jakthund.

Han som härstammar från dharmakungarnas ätt utförde en rånares dåliga handlingar.

Vattnet som samlats i ett hovavtryck från boskap likställdes med en hel ocean. ${ }^{195}$

De fattigas mat och tillhörigheter togs till de rikas skattkammare. 
Ett grässtrå beskärdes

som vore det ett rosenäppelträd. ${ }^{196}$

Efter att ha stulit de fattigas ägodelar

försåg kungen sig själv.

Det allra tydligaste tecknet på detta var

kungens stöld av vasen som tillhör

tiggarnas vän, den anspråklöse mannen från östra Tibet.

Om detta verkligen skulle visa sig vara sant, ber jag kungen att se till att lämna tillbaka det han stulit.

Om det som stulits återlämnas, som ett resultat av budskapet i denna enkla sång, kommer tre sorters glädje uppstå:

Jag, dåren, blir glad om konungen lyssnar till en yogis påminnelser.

Den rättmätiga ägaren till det som stulits blir glad om han får tillbaka sina tillhörigheter och han känner inte längre hat och illvilja.

Kungen blir glad eftersom stöld av andras egendom resulterar i fattigdom och han blir befriad från de hungriga andarnas tillstånd.

Därför ber jag dig återlämna alla de ägodelar som du stulit.

Detta är en dåres uppriktiga råd, en som själv inte vågar utföra dåliga handlingar.

Om du inte ger tillbaka det du stulit och kungen inte lyssnar till tiggarna, har jag inget mer att säga.

Just så är det.

Eftersom det är sant att orsak och verkan inte går att undslippa, kommer kungens stöld av andras egendom resultera i fattigdom och så vidare.

Du måste ofrånkomligen uppleva detta. Just så är det. 
Också de som är fattiga och inte äger någon rikedom har tagit andras ägodelar i tidigare liv.

Detta visar tydligt orsak och verkans ofrånkomlighet.

Just så är det.

Om dessa tre sanningar

blir förstådda, är de meningsfulla för kungen.

Men om de inte leder till insikt, är de en dåres sludder.

Jag är ännu inte färdig med denna spontana sång.

Jag har hört att de forna dharmakungarna

gav gåvor till de kännande varelserna.

$\mathrm{Nu}$ ser jag en kung som tillhör dharmakungarnas ätt som stjäl, till och med från de som är fattiga.

Om vi ska sörja något, ska vi sörja detta.

En kung ska ge trygghet till de kännande varelserna.

Men nu agerar kungen på ett hotfullt sätt.

Om vi ska känna vrede över något, ska vi känna vrede över detta.

Under en dharmakungs styre ska tjuvar bestraffas.

Men nu uppför sig kungen själv som en tjuv.

Om vi ska gråta över något, ska vi gråta över detta.

En kung ska sitta på sin tron. Men denne kung vältrar sig i rikedom från utslagna leprasjuka tiggare.

Han gör detta på gatan tillsammans med horder av tjuvar.

Om vi ska skratta åt något, ska vi skratta åt detta.

Denna spontana sång är ännu inte slut:

En kung med ett ypperligt uppförande som förbjuder jakt av vilda djur och vet att avstå från negativa handlingar, 
vinner världsligt beröm och gott anseende.

Han är också källa till dygd som glädjer de segerrika.

Det finns ingen annan sanning än

handling, orsak och verkan.

Från första början är det upphovet till detta liv.

Om orsak och verkan inte vore fullständigt sant

skulle dottern till en uggla

och sonen till en kråka

förenas genom en ofruktsam kvinnas son.

Iklädda en klädedräkt gjord av sköldpaddshår

och utsmyckade med vackra smycken som inte existerar

skulle de,

på ett säte som består av lotusblommor som växer i himlen

och en tron gjord av horn från harar,

fyllda av glädje hoppa omkring och leka.

Detta skulle ses av alla varelser.

Evam!

Så sjöng Tsangnyön och sångens innehåll gjorde alla som samlats mycket hängivna. De tittade på varandra och knuffade på varandra i samförstånd. Kungen återlämnade vasen och började därefter uppföra sig på ett sätt som var till gagn för andra. 


\section{EN SÅG MED SVAR PÅ PRINSESSAN DZAMLING OCH KHANDRO SANGMOS FRÅGOR}

När våren sedan kom, begav sig mästaren tillsammans med sina lärjungar till Det klara ljusets grotta i Ronphu, ${ }^{197}$ en grotta där den vördade Mila hade utövat meditation. Medan de vistades där kom kungens halvsyster och dotter, Dzamling och Khandro Sangmo, och bad om dharmaundervisning. ${ }^{198}$ De två bad envetet om att Tsangnyön, till varje pris, skulle ge dem en sång med instruktioner som var lätta att förstå. Tsangnyön sjöng då denna sång:

Med de tre portarna fyllda av respekt, bugar och lovprisar jag inför de strålande kagyulamorna.

Lyssna drottning Dzamling: "mor" och dotter! ${ }^{199}$

Om ni anser att mitt tal, en galning som vandrar runt i världen, är sant ska jag sjunga en sång med innerliga råd. Råd som alltid är till nytta, nu och i framtiden. Behåll dess budskap i era hjärtan!

Efter att de fötts, kommer alla kännande varelser som vistas på jorden helt säkert att dö.

Men, ingen vet när döden kommer att inträffa. Utför därför kontinuerligt goda handlingar, dag och natt!

Även om vi inte förbrukar den rikedom som vi samlat i detta liv, kommer den att gå förlorad när vi dör. Sluta därför att samla på rikedom och negativa handlingar. Ge gåvor utan att ha några förväntningar eller begär!

Vi måste skiljas från våra syskon som fötts från samma föräldrar som vi själva.

Detta gäller också nära vänner som vi träffar senare i livet.

Ge därför upp era bindningar gentemot nära och kära. Lev i avskildhet och utöva läran som hjälper när döden kommer! 
När vi har samlat ägodelar

och är förskonade från negativa omständigheter, tycker vi oss ha goda kunskaper om dharma.

Men när vi slutligen dör går kropp och sinne skilda vägar.

Förena utövningen med omständigheterna ni möter!

Jag, dåren, ska ge er fler innerliga råd:

Vad beträffar uppförandet under detta liv när ni är i min närhet: Ansträng er i dharma utan att vara distraherade ett enda ögonblick!

Vad beträffar uppförandet under detta liv när ni är bland andra: Rena er från fel, tillkortakommanden och orenheter;

sätt på er omtänksamhetens och anständighetens kläder och smycken!

Eftersom de alltid gör er rika, nu och i framtiden, samla ihärdigt de sju ädla rikedomarna! ${ }^{200}$

Eftersom ni alltid önskar klokhet och skönhet, avstå från dåliga handlingar och utöva i stället goda handlingar!

Eftersom fenomenens natur saknar bindningar, sluta med allehanda komplicerade befrielsemetoder!

Om ni håller detta i sinnet kommer de djupa instruktionerna att visa er den segerrikes sinne.

Evaṃ!

Så sjöng Tsangnyön, och Dzamling samt Khandro Sangmo utövade därefter det som uttryckts i sången med stor ihärdighet. 


\section{INSTRUKTIONER TILL HÄRSKARINNAN SÖNAM SANGMO}

Därpå fick Tsangnyön brev från härskarinnan av Tenkheb, Sönam Sangmo. ${ }^{201}$ Sönam Sangmo hade vid denna tidpunkt blivit förd till härskaren av Tsamda för att bli dennes fru. Men eftersom hennes tilltänkte make plötsligt dog, blev härskarinnan tvungen att återvända till sin hemtrakt. Sönam Sangmo hade sedan länge haft en välgörare-lärare-relation med Tsangnyön och när hon nu befann sig i denna svåra situation väcktes hennes stora hängivenhet till den dyrbare mästaren. Hon bad enträget Tsangnyön ge henne en instruktion som är till nytta för sinnet. Som svar på hennes önskan skickade Tsangnyön henne detta brev:

Full av respekt lovprisar och bugar jag mig inför kagyulamorna!

Flicka, Sönam Sangmo!

Jag hörde det sägas att omständigheterna som kännetecknar det sammansatta i landet där vi blivit födda, har fått ditt sinne att ändra riktning.

Om detta verkligen är sant, eftersom vårt nuvarande livs välgörare-lärare-relation är frukten av den godhet som våra föräldrar i tidigare liv visat oss, ska jag på grund av min medkänsla förmedla tre innerliga råd på vägen.

Glöm dem inte utan håll dem i minnet och utöva dem kontinuerligt!

Eftersom lamorna och de tre juvelerna är fullständigt tillförlitliga be om tillflykt i detta och i nästa liv! Eftersom alla sex kategorier av kännande varelser varit dina omtänksamma föräldrar, 
återgälda deras godhet

och ta hand om dem med kärlek!

Det är nödvändigt att vara till gagn,

både för sig själv och andra.

Fullända ditt avståndstagande från tillvarons kretslopp och fullborda också din befrielse.

Vårda uppvaknandets frö!

Se hur död följer födelse och,

eftersom vi inte vet när döden inträffar, inse att det är brådskande.

Ägna dig åt dharma dag och natt!

Se hur det som byggts upp

faller samman,

överge bindningar till djurhållning, husbygge

och bebodda platser.

Vandra runt i vildmark och bland ensliga boningar!

Uppmärksamma hur det som samlas ihop förgås.

Genom snålhet uppnås de hungriga andarnas tillstånd.

Sluta utföra negativa handlingar för rikedoms skull

och ta fasta på det meningsfulla i rikedomen! ${ }^{202}$

Inse hur allt som kommer samman skiljs åt.

När du tänker på ditt tidigare lidande

så är enbart just detta tillräckligt.

Skär av ditt begär till vänner!

Just nu är du välsignad med förtjänster, men självbestämmandet

som du nu uppnått går förlorat

om du låter dig styras av andra.

Fäst därför "nosrepet" på ditt huvud! ${ }^{203}$

Återigen ska yogin, dåren från Tsang,

ge dig innerliga instruktioner

som uppfyller dina önskningar:

Om du önskar kontinuerlig lycka och glädje, fly från saṃsāras fängelsehålor! 
Om du önskar vidsträckta njutningar och rikedomar som aldrig tar slut, se till att ihärdigt öka de två samlingarna!

Om du önskar förstå den segerrikes tillstånd, bortom födelse, kasta ut subjekt-objekt-uppdelningens demon!

Om du vill att allt det du varseblir ska framträda som undervisning, studera ditt eget sinne!

Om du önskar nå uppvaknande i detta liv, utöva utan några förväntningar!

Om du önskar dra dig tillbaka från saṃsāras slagfält, besegra fiendens arméer, jagbundenheten!

Om du vill att den dyrbara mänskliga tillvaron ska bli meningsfull, tänk på de tre lägre världarnas lidanden!

Om du önskar förverkliga din meditationsgudomlighet, skada inte dina samayaåtaganden och utför dina rituella övningar!

Om du vill att lamans välsignelse ska fylla ditt hjärta, bryt inte mot hans eller hennes instruktioner, utan följ dem till punkt och pricka!

Om du vill att modergudinnorna och ḍakinierna ska stödja dig, håll fast vid dina samayaåtaganden med stor kraft, i enlighet med skrifterna!

Om du vill att dharmabeskyddarna och väktarna ska utföra sin verksamhet, fullborda utövningen genom att offra torma och utföra tacksägelseritualer! Om du vill galoppera på sällhetens vidder, rid på metodens och visdomens häst! 
Om du önskar förstå din egen natur, avlägsna de tillfälliga föroreningarnas slöjor!

Utöva enligt dessa råd!

Om du förstår dem är de bättre än en hel förmögenhet. Om du inte förstår dem avklingar ljudet i tomma intet!

Sangmo, ta emot denna förmögenhet!

Låt detta bli mina instruktioner när du reser, också om du stannar på en plats, har jag inga andra instruktioner beträffande hur du ska utöva än dessa.

Om du utövar dem kommer de att vara till nytta för dig.

I Det klara ljusets grotta, från Det klara ljusets sfär, för att Sönam Sangmos förtjänster ska öka, nedtecknades detta brev av en son till kagyumästarna, i enlighet med kagyutraditionens muntliga undervisning.

För att göra brevets budskap oföränderligt har jag lindat in det i ett stycke silke och knutit en mantraknut runt omkring, därefter sänder jag det.

Evam! 


\section{INSTRUKTIONER TILL HJÄRTESONEN MÖNDZE}

TOGDEN INFÖR HANS RESA TILL KAILASH

Därefter blev Tsangnyön och hans lärjungar inbjudna av Dowochewa. ${ }^{204}$ De begav sig därför iväg för att gagna alla varelser. Sedan färdades de ännu en gång till Gungtangs huvudstad. ${ }^{205}$ När de vistades där sände Tsangnyön iväg sin hjärteson Möndze Togdenpa för att han skulle resa utövningens segerbaner vid Kailash. ${ }^{206}$

Innan han reste sade Möndze Togdenpa:"Visa mig medkänsla och ge mig muntliga instruktioner som visar hur jag ska utföra dygderika utövningar när jag reser för att utöva i Kailash. Ge mig en instruktion som avslöjar mina fel men också visar hur jag ska utöva på ett sätt som är enkelt att tillämpa.” Som svar på denna förfrågan sjöng Tsangnyön denna sång som fullständigt avslöjar fel:

Du har direkt insikt i att dharmatā, den yttersta verkligheten, till sin natur är en smak.

Du har kunskap om allt som existerar, varje fenomen utan undantag. Din visdoms sol och din medkänslas måne skiner på kunskapens himmel. Jag bugar inför dina fötter, o lama! Du som klargör allting!

För att hjälpa min trogne lärjunge, sjunger jag, en yogi som följer de tre traditionerna, ${ }^{207}$ denna spontana sång.

Jag ber dig att inte glömma den, utan bevara den i sinnet.

Det är på följande sätt du fullständigt ska avslöja dina fel, samt utöva på vägen mot uppvaknandet.

Att inte ge upp världsliga tankar och handlingar när du avlägsnat tecknen på det världsliga 
och antagit en munks yttre skepnad.

Detta är ett fel som du ska avstå från.

Att inte vara fri från materiella begär när du lämnat hemlandet bakom dig och vandrar land och rike kring, utan mål.

Också detta är ett fel som du ska avstå från.

Att överväldigas av begär

till de åtta världsliga angelägenheterna

när du vandrar i ensliga bergsområden, utan följeslagare,

och utövar asketism samt lever på endast vatten.

Också detta är ett fel som du ska avstå från.

Att fullt medvetet strunta i

att utföra goda handlingar

och inte avstå från att utföra negativa handlingar,

fastän kunskapen i skrifterna är omfattande.

Också detta är ett fel som du ska avstå från.

Att inte visa hängivenhet och vördnad, utan söka efter fel och vara fylld av rivalitet, när du förlitar dig på oräkneliga lamor.

Också detta är ett fel som du ska avstå från.

Att förklara dharma och ge rituella invigningar

med hjälp av exempel och anvisningar

som är färgade av begär efter de åtta världsliga angelägenheterna, när du inte har mött någon enda tradition.

Också detta är ett fel som du ska avstå från.

Att omedveten om din egen obetydlighet, med kraft proklamera att du har goda egenskaper, som du inte har.

Och att framstå som om du har mycket ren syn inför dina vänner. Också detta är ett fel som du ska avstå från.

Det är nödvändigt att skämmas

för dina mycket stora fel, inför laman och de tre juvelerna, 
men än större är nödvändigheten

att känna skam inför dig själv,

så skäms över dina egna fel!

För den som har förmågan att känna skam inför sig själv

finns inget större fel än att inte skämmas

över sina egna tillkortakommanden.

Att inte avstå från det som är fel, fastän du förstått att det är felaktigt, är som att hoppa utför en klippa fast du ser stupet, eller som att äta dödligt gift utan att kunna mantra. ${ }^{208}$ Vad kan vara mer idiotiskt och dumt än att medvetet skapa de lägre tillstånden. Detta är ofruktbart och uselt.

Det förändrar dessutom hjärtat och är inte möjligt att betrakta som kunskap.

Var ödmjuk, anamma en låg position och ha inte högt ställda förväntningar.

Om du handlar på detta sätt från och med nu så vore det utmärkt. Jag ber dig uppmärksamma fel och brister sålunda och utöva såsom jag beskrivit i denna sång!

Denna mänskliga kropp, där friheter och möjligheter kommit samman, liknar en fattig människa som får ett kungaslott. Jag ber dig att med svårfunnen och otvungen glädje förstå hur sällsynt den är.

Dessa friheter och möjligheter är svåra att uppnå. Det finns få omständigheter som upprätthåller livet, men många omständigheter som leder till döden. Dessutom kommer döden plötsligt som blixten. Jag ber dig vara medveten om att det är brådskande.

Den nuvarande tillvarons all lycka och lidande är frukten av tidigare god och dålig handling, om du önskar uppleva lycka och glädje i framtiden, undvik dåliga handlingar och utöva goda handlingar nu. 
Om blotta tanken på de tre lägre tillståndens lidanden kan få dig att kräkas blod, hur skulle det då vara att uppleva dem?

Utöva därför helt fokuserat.

Laman och de tre juvelerna är osvikliga, ta därför din tillflykt.

Utför så mycket goda handlingar du kan med kropp, tal och sinne och tillägna förtjänsten alla varelser för att de ska uppnå uppvaknandet.

Allting är gudomligt till sitt ursprung,

överge därför alla orena subjekt-objekt-orienterade uppfattningar.

Det rena gudomliga skapas inte, vila därför i ett sinnestillstånd utan aktivitet.

Om du utövar på detta sätt, för att uppnå stabilitet i utövningen som frammanar insikt, ${ }^{209}$ agerar du på ett sätt som motverkar det världsliga.

Om du utövar den kraftfulla disciplinen för att bli berömd kommer karmaḍākinīernas avundsjuka att orsaka allehanda missöden i ditt nuvarande liv och en födelse i vajrahelvetet i ditt nästa liv. Utöva därför endast den kraftfulla disciplinen ${ }^{210}$ för att uppnå uppvaknande!

Son, om du önskar sträva efter det som är meningsfullt i framtida liv,

ska jag, en galen yogi, återigen

ge dig innerliga instruktioner och illustrera dessa med exempel.

När du ska resa utövningens segerbaner, se på järnspettet som är fast förankrat i marken. Utöva utan att rubbas!

När du ensam vandrar runt bland bergen, använd noshörningen som exempel.

Utöva utan att misströsta! 
När du vandrar land och rike runt utan mål, använd fädern som virvlar runt i vinden som exempel. Utöva utan bindningar!

När du möter överflöd och rikedom, använd den illamåendes mat som exempel.

Utöva utan begär och bundenhet!

Nu ska jag, en galen yogi, sjunga en sång om den fulländade meningen.

Var god och glöm den inte, utan bevara den i ditt sinne!

Fastän de önskar uppleva lycka, upplever varelserna lidande, just detta är svaret på deras önskan att uppnå lycka. Därför vore det bra om varje sådan längtan ges upp.

Rent allmänt vore det bra om alla önskningar upphörde. Den yttersta gränsen för alla önskningars upphörande är när längtan efter uppvaknande upphör.

Alla fenomen som skapas i sinnet är i själva verket bortom det begreppsmässiga tänkandet. Också den djupa läran som meditativt skapats i sinnet är till sin natur endast okunnighet.

Att inse meditationens mening är som att se sitt eget öga.

Eftersom både den som mediterar och meditationen är sinnet kan du inte förstå meditationen med ditt intellekt.

När du inte förstår är du bortom intellektualiserande.

Då har du förenat de tre: synsättet, meditationen och uppförandet, och genom detta kommer du bortom utövande. Att vara bortom utövande är den högsta yogan.

Detta är min, yogins, hela insikt.

Behåll detta i sinnet, Kunga Legsang! Praktisera på de särskilt heliga platserna, Kailash och så vidare! 
Det är möjligt att detta också är dårens sista ord till dig.

Om detta skulle bli mina sista ord

kommer vi att mötas i ḍakinīernas rike.

Låt detta bli dharmaundervisning inför din resa!

Jag ber att du ska möta lycka och vara i harmoni med dharma!

Evam!

Efter att ha sjungit sålunda sände Tsangnyön iväg Möndze Togdenpa och genom sin utövning i Kailash och på andra heliga platser uppfyllde Möndze Togdenpa sitt åtagande. 


\section{BREV TILL HJÄRTESONEN SÖNAM DRUBPA}

Namo guru! Därpå, när den dyrbare mästaren vistades i Gungtang, blev han inte inbjuden till Lachi av Tsamdas härskare. Där fanns dock Zhingring Chödes mästare, Sönam Drubpa, som studerat och reflekterat över sūtra- och mantratraditionerna och sedan länge hyste mycket stor hängivenhet till Tsangnyön. Han skrev hela tiden brev där han utförligt skildrade varför det var nödvändigt att Tsangnyön satte lärans hjul i rörelse i Lachi. Tsangnyön svarade med följande brev:

Jag bugar inför kagyulamorna!

Jag har mottagit en kontinuerlig ström av brev från dig, lärde vän.

Eftersom du skrivit dem med kärlek är det också med glädje jag förstår brevens innehåll.

Käre vän, du nämnde bland annat

att du vill att jag ska förklara dharma med sex utmärkta egenskaper. ${ }^{211}$

Eftersom du behöver detta och vi har en förbindelse till varandra sedan tidigare, ska jag ge dig detta svar:

För mig, yogin, är tankeprocesserna dharmakāya, och det sägs att alla fenomen, saṃsāra såväl som nirvāna, är tomhet, oskapade till sitt ursprung.

Det är skillnad om man upplever förtroende eller inte upplever förtroende, och om man känner igen sin egen natur eller inte.

Det är utifrån detta som förmågan att utföra det som är meningsfullt eller oförmågan att göra detta uppstår.

Detta exemplifieras på följande sätt:

En obegåvad person bränner sandelträ till kol. 
Och medan en fattig person, som önskar uppnå vinst, tröttar ut sig genom att hämta kol vid sidan av ett guldberg förlorar inte guldberget sitt värde.

Genom gynnsamma omständigheter förstår man att berget är av guld, men guldberget blir inte bättre än det redan är.

Efter att den fattige personen har slutat arbeta med kol skingrar guldet all fattigdom.

På liknande sätt är det för en yogi

som känner igen de störande tankarnas natur.

Eftersom de störande tankarna känts igen som dharmakāya, kan rörelse i sinnet accepteras.

Det finns inte längre något behov av att undertrycka (negativa handlingar) eller frammana goda handlingar.

Om du önskar fastställa vad denna tradition handlar om en gång för alla:

Utifrån sett är den i överensstämmelse med skrifter och logiskt resonemang. Inifrån sett är den i överensstämmelse med erfarenheter och inre förtroende.

Käre vän, du förstod säkert redan att denna, en galen yogis, tradition också är den högsta av alla.

Om du inte accepterar att de störande tankarna i sinnet är dharmakāya, accepterar du inte min, yogins, tradition.

Då missförstår du också mina förklaringar.

Käre vän, denna tradition innehåller noggranna förklaringar som har sitt ursprung i den rena synens sfär. Även om jag blir kvar i Mangyul en kort period och den heliga platsen Lachis invånare lider av törst, 
kommer jag, liksom öppenheten i sinnet, den svalkande floden, om jag får leva, med säkerhet till Lachi.

Och vid denna tidpunkt kommer jag att ge er utförliga instruktioner och förklaringar.

Dessa ord uttrycker den högsta meningen i evaṃs tillstånd. De skrevs ner på den grundläggande likhetens dag, och är bortom förklaringar. Dygd.

Evam! ! 


\section{BREV TILL MUNKEN NAMKA GYALTSEN}

Samtidigt som detta tilldrog sig fanns det dessutom en utövare från Lachi vid namn Drakshog Namka Gyaltsen. Han hade mycket stor visdom och ren syn och var väldigt hängiven Mästaren. Men han hade inte möjlighet att själv resa till Gungtang, eftersom han var tvungen att ta hand om sin mor och far. Därför skickade han ett brev som förklarade varför det var nödvändigt att Tsangnyön satte lärans hjul i rörelse i Lachi. Som svar sände Tsangnyön honom detta brev:

Jag bugar inför kagyulamorna!

Jag har mottagit ett brev från buddhistmunken Namka Gyaltsen. Brevet visar att Namka Gyaltsen har ren syn.

Jag förstår brevets innehåll och svarar med dessa ord:

Du kallade stjärnorna för sol och måne, och nämnde att du behöver den stora farkostens heliga dharma - ljuset. ${ }^{212}$

Om havet med de åtta egenskaperna

- dina lamor som förlitar sig på de tidigare mästarna:

Duldzin Ngawang, Rechen Chöje och så vidare - ${ }^{213}$

inte gör dig tillfredsställd, kommer verkligen inte en vattenpöl

- det vill säga den galna yogins babbel, att tillfredsställa dig.

Nåväl, i likhet med att det i de fattigas hem kan finnas rikedom som saknas i kungens skattkista, och de som inte blir befriade av Buddha kan befrias av munkarna och nunnorna i hans följe, så är det möjligt att jag också kan vara till nytta för dig.

Eftersom du har välsignelsen från de tidigare lamornas tradition har du redan uppnått mognad och befrielse.

Men, på samma sätt som att man inte ska nöja sig 
med ett helt hav fullt med vatten, är det bra att inte nöja sig med ett hav fullt av goda egenskaper.

"En dålig skinnsäck men ett bra handtag", säger vissa folkliga talesätt.

På samma sätt är jag själv dålig, men den överförda traditionen är mycket bra. Kagyulamorna är min traditionslinje och på grund av detta innehar jag den stora farkostens heliga dharma.

Jag behärskar metoden som spontant inser den egna naturen.

Saṃsāra som nirvāṇa, och de störande tankarna som dharmakāya. Metoden som tillintetgör hjärtat och hjärnan hos śrāvaka- och pratyekabuddhatraditionernas låga synsätt. Jag har instruktionerna som leder till självinsikt utan att behöva göra avkall på något, traditionen där orenheterna i sinnet är en del av vägen till uppvaknande.

Eftersom den galna yogins tradition genomtränger de segerrika, såväl som de lägre världarnas varelser, utan att lägga till eller ta ifrån, finns inte någon önskan att ge upp någonting. Traditionen känner inte heller till någon metod för att ge upp någonting.

Oavsett om varelserna är rena eller orena är deras natur dharmatā

- det klara ljuset, mahāmudrā.

Himlen kan inte avstå från sin rymd.

Ej heller elden från sin värme, eller vattnet från sin fukt.

Eftersom själva icke-vetandet är mahāmudrā är varelserna aldrig åtskilda från meditationen. 
Men om de inte har fått instruktionerna som är välsignade av traditionslinjen, upplever de lidande och vet varken vilka handlingar de ska utföra eller vilka de ska avstå från att utföra.

Orsaken till detta är att de då inte känner igen sin egen natur och lever i villfarelse.

Meditationen blir då fixerad vid att uppnå nirvāṇa och ta avstånd från saṃsāra. ${ }^{214}$

Fastän det inte är sann meditation befinner de sig i ett tillstånd de kallar meditation.

Detta resulterar i śrāvaka- och pratyekabuddhatraditionernas okunnighet och omognad.

Jag är en yogi vars meditation är bortom intellektualiserande. Eftersom min tradition inte ser något meditationsobjekt är dåren avslappnad och strålande.

När du får möjlighet att förklara detta utförligt för dina föräldrar, som visat dig kärleksfull godhet i detta liv, gör då det.

Återgälda deras godhet, hjälp dem att uppnå lycka och beskydda dem från lidandets ödemarker.

De kännande varelserna - lika många som himlen är stor, våra godhjärtade föräldrar vandrar runt i de negativa handlingarnas och lidandets ödemarker.

Där finns ingen som hjälper dem att finna godhet och lycka.

Subjekt-objekt-uppdelningens banditer har rest sig från sitt bakhåll, och med de fem gifternas vapen i sina händer har de stulit våra föräldrars nuvarande och framtida lycka samt deras egendom.

Utan skeppet som tar dem över lidandets fyra floder ${ }^{215}$ vandrar de och även andra runt i saṃsāras ödemarker, där inte ett enda ögonblick finns av glädje och lycka. 
Det vore bra om du,

för att skydda dina föräldrar från fruktan, och för att skänka dem outtömligt välmående

- den stora farkostens rikedom, mognad och befrielse utövade med full koncentration utan att bry dig om detta livets angelägenheter.

Också jag, yogin, har godhjärtade föräldrar, och det är genom den heliga dharma jag återgäldar deras godhet.

Mina föräldrars godhet kommer helt säkert att återgäldas.

Men jag återgäldar inte deras godhet med några småsaker.

I stället uppfyller jag deras önskningar på högsta tänkbara sätt. Jag, den galna yogin från Tsang som vandrar land och rike kring, använder min kropp och mitt sinne till att resa utövningens segerbaner på de tre heliga platser som välsignats av kagyulamorna. Jag ber också dig, yogi, att vara flitig i din utövning.

Du önskar återgälda dina föräldrars godhet. Men om deras godhet inte kan återgäldas genom alla ädla människors utövning, kan den inte återgäldas genom att du tar hand om dem i detta liv.

En smörlampa kan inte ersätta solen och månen. Men när det saknas ljus från solen och månen, eftersom du då vistas i mörker, är en lampas ljus till nytta.

Förstå detta, o du yogi!

Tanken på att strunta i mina föräldrar har också någon gång funnits hos mig, en dålig son till en kärleksfull mor.

Men eftersom jag inte glömmer mina föräldrar, ens när jag drömmer, har jag i sista stunden, innan de fyra elementen separerats från varandra, ${ }^{216}$ 
återvunnit min sans.

Medan du ännu lever, ber jag dig:

vila naturligt, utan att hindra eller skapa

objekten du varseblir med de sex sinnena. ${ }^{217}$

Detta skrev jag när jag befann mig i evam, tillståndet som inte kan uttryckas.

Jag skrev det på den grundläggande likhetens dag. Må dygd och godhet öka!

Evam! 


\section{EN SÅNG DÄR UTÖVNINGEN BESKRIVS MED HJÄLP AV OANSTÄNDIGT TAL}

Därefter avböjde mästaren och hans lärjungar kungen av Gungtangs envetna begäran om att stanna. I stället gav de sig av, och när de kom till Nyanang stannade de i Maitreyas tempel. Då kom en meditationsutövare som var minister i Shriri (Tsibri) och bar namnet Palden Sangpo. Han sade: "Ge mig en undervisning som är lätt att förstå och tillämpa."

Som svar sade Tsangnyön: "I så fall, eftersom allt som uppstår är exempel på utövning för en yogi, är just dessa exempel särskilt lätta att förstå.”

Därpå sjöng han sången som förklarar utövningen med hjälp av oanständigt tal.

\section{Namo guru!}

Jag, en galen yogi som vandrar land och rike kring,

ska med hjälp av utmärkta exempel som snabbt blir ihågkomna, på ett underhållande sätt,

förklara synsättet, meditationen och uppförandet för dig, yogi, Palden Sangpo.

Exempel på synsättet - som är att sinnet inte följer efter tankarna: det finns inget idealiskt mått på vaginans djup;

låt sinnet vara som när du av njutning förlorar medvetandet under samlag!

Exempel på meditationen - som är klarhet och tomhet utan fastklängande:

den liknar en man och kvinna som ännu inte har träffats. Upprätthåll uppmärksamheten utan ett ögonblicks distraktion!

Exempel på uppförandet - som är oupphörlig spontanitet: var utan hyckleri, hemlighetsmakeri och snålhet, liksom könsorganen som gnids emot varandra.

Utöva med samma iver som när penisen befinner sig invid slidans öppning! 
De egna upplevelserna ska hållas hemliga; skydda dem som du skyddar en drottning från andras beröring! De åtta världsliga angelägenheterna är lika onödiga som en mage uppblåst av gas.

Gör dig av med dem!

Följ och ära laman med samma intresse som unga förälskade män och kvinnor visar för varandra!

Låt dessa instruktioner framkalla skratt. Om du utövar dem är de till nytta för sinnet. ${ }^{218}$

Denna sång väckte omedelbart en djup insikt inom Palden Sangpo. 


\section{DEN STORSLAGNA SÅGEN SOM FÖRKLARAR DRÖMMARS MENING}

Därefter reste den dyrbare mästaren och hans lärjungar till Lachis bergsområde. När de vistades där och utövade för andras välgång upplevde en av lärjungarna, hjärtesonen Jigme Drakpa, underbara tecken i en dröm. Han beskrev sina upplevelser för Tsangnyön på följande vis:

Genom att se, höra eller tänka på dig blir varelserna lyckliga. Jag bugar mig inför fadern, siddhornas kung, du som genom att utöva kraftfull disciplin har inträtt på den högsta vägen och etablerar de lyckligt lottade på mognadens och befrielsens väg!

Under den sista delen av den gångna natten, i en dröm som uppstod när jag sov, i himlen framför mig, såg jag dig - mästaren, den gode laman. Du befann dig i en tältliknande kupol som bestod av femfärgade regnbågar, där var du framför mig i himlen.

När jag såg detta uppstod förundran och glädje, men eftersom det jag såg inte var verkligt, mediterade jag på den drömlika illusoriska naturen. Jag såg att den övre delen av regnbågen var något otydlig, men att den nedre delen var skinande och klar.

Då började himlen framför regnbågen att vibrera, och därpå - på grund av den stora kraften hos mina dharmasyskon blev vi accepterade som dina lärjungar.

Rinchen Palsang var den som först blev accepterad som lärjunge.

När detta skedde slutade himlen att vibrera, 
och vi satt framför dig utan att vidröra marken. Jag såg en cirkel i regnbågsljuset.

Efter detta förvandlades allt och på ett ögonblick visade sig en väldig fågel.

Fågeln svävade majestätiskt ovanför ett fält med gula senapsblommor.

Från undersidan av dess majestätiska vingar strålade ljus, och när ljuset strålade på de gula blommorna blev blommorna skimrande vackra.

Därpå landade fågeln på marken och gick in bland de skördade senapsblommorna.

Var snäll och berätta vad detta betyder!

När han hade frågat detta, sade Tsangnyön, mästaren, laman och siddhan: "I allmänhet är alla de tecken som uppstår i drömmen obeständiga och därför overkliga. De är exemplet som visar att allt det som vi förnimmer i den yttre världen under dagen också är overkligt.

Men tillvarons kretslopp fortsätter så länge vi delar upp tillvaron i två sanningar, och de forna kagyumästarna höll utövandet av yogins upplevelser - sådant som dröm och klart ljus - som helt nödvändiga. O son, därför ska jag förklara betydelsen av din dröm.”

Därpå sjöng Tsangnyön den storslagna sången som förklarar drömmars mening och förutsäger den spontana aktivitet och nytta för de kännande varelserna som ska uppstå i framtiden.

Genom sina många dharmaaktiviteter, sprungna ur tomhetens natur, den allomfattande rymden, handlar de för att gagna varelserna som fyller himlen.

Jag bugar inför kagyumästarnas fötter! I synnerhet bugar jag inför mästaren, Rabjam!

I deras anda sjunger jag, yogin, en sång. Förstå dess mening, Jigme Drakpa!

Om denna sångs mening blir förstådd finns här de två sanningarna samlade. 
Vi är vana vid att hålla fast vid det vi förnimmer under dagen som verkligt, medan overkligheten, tomheten, illustreras av illusionen och av drömmarna som uppstår under natten och inte kan förklaras.

Inse att alla ting, såväl som drömmar och illusioner, är overkliga!

Följaktligen, med utgångspunkt i de två sanningarnas framträdanden,

likställs de med drömmar av de enastående kagyumästarna.

Därför ska jag förklara betydelsen

av de drömmar som du hade i natt.

O du lyckosamme, i din dröm

framträdde jag, din huvudsaklige lärare,

i himlen framför dig.

Jag vistades i ett tält som bestod av femfärgade regnbågar, och befann mig i himlen.

Detta är ett tecken på att

de som tillhör de forna kunskapsbärarnas traditioner i alla tider befinner sig i de himmelska sfärerna.

Den tältliknande kupolen som bestod av femfärgade regnbågar är ett tecken på att de fem visdomarna har framträtt.

Att jag fanns i mitten av detta

är ett tecken på att jag tillhör kunskapsbärarnas sällskap

och har uppnått den himmelska nivån.

Att du, yogin, såg detta

och kände förundran och glädje, är ett tecken på att traditionslinjens välsignelse har trätt in i dig.

Att du dessutom insåg att detta inte var verkligt, är en påminnelse om vakenhetens dharmatā.

Att den övre delen av regnbågen var något otydlig är ett tecken på att du, eftersom dina subtila kanaler, din subtila vind och dina subtila essenser varit svaga, genomled svårigheter i början av ditt liv. 
Därför stördes dina upplevelser av sällhet, klarhet samt icke-tänkande.

Och du var endast ringa kapabel att gagna andra.

Att den nedre delen av regnbågen var klar och strålande är ett tecken på att du senare i livet,

genom traditionslinjens välsignelse och de fem visdomarnas aktivitet, renat alla buddhaländer. ${ }^{219}$

Samt att du fått kraften och förmågan att föra varelserna till mognad och befrielse.

Att himlen precis framför dig började vibrera är ett tecken på att din tro gjorde traditionslinjens upprätthållare glada.

O son, att Rinchen Palsang var den av er som först framträdde är ett tecken på att det var han som först tog del av min traditionslinjes alla välsignelser.

Eftersom ni blivit accepterade som lärjungar nådde ni nästan inte till marken.

Detta är ett tecken på att ni inte längre är bundna av den tvåfaldiga uppdelningen i subjekt och objekt.

Att ni nästan hade kontakt med marken är ett tecken på att ni tar hand om alla varelser genom er medkänsla.

Cirkeln i mitten av regnbågsljuset symboliserar självinsiktens klara ljus.

Efter detta blev allting förvandlat och plötsligt visade sig en ensam stor fågel.

Detta är ett tecken på att synsättet skär genom skyn.

Den gula utslagna sesamblomman symboliserar de goda egenskaperna som utvecklats hos lärjungarna, likt en utvecklad sesamblomma. ${ }^{220}$ Att fågeln svävade ovanför blomman symboliserar traditionslinjens välsignelse. 
Ljuset under fågelns vinge symboliserar ljuset i traditionslinjens kärlek och vishet.

Att ljuset strålade på blomman

symboliserar att lamans välsignelse nått lärjungarna.

Att blomman strålade av skönhet

symboliserar att välsignelsen trätt in i lärjungarnas medvetanden, och att också lärjungarna som upprätthåller traditionslinjen gagnar vem som än får kontakt med dem.

Därefter landade fågeln på marken och trädde in bland skörden av blommor.

Detta symboliserar att alla vi som upprätthåller traditionslinjen, efter att fullständigt gagnat de kännande varelserna, och vistats i alltings grundläggande natur - dharmatā förblir i det ultimata uppvaknade tillståndet, men samtidigt gör vi, med hjälp av de fyra kropparnas strålglans, överflöd och godhet, den inre rikedomen tillgänglig för alla kännande varelser.

O son, den gångna nattens dröm är förträfflig.

Den är lyckosam och lyckobådande. ${ }^{221}$

Drömmen visar att vår tradition kommer att vara till oändligt stor nytta för alla de kännande varelserna. ${ }^{222}$

Sådan är min profetiska sång.

Evam! 


\section{INSTRUKTIONER TILL DÖNDRUB RABSEL FRÅ KHARKHA - SANGEN OM DET TILLFÄLLIGA OCH DET SLUTGILTIGA}

Vid ett annat tillfälle kom en lärjunge vid namn Döndrub Rabsel för att be Tsangnyön om råd. De var födda i samma område och Döndrub Rabsel bad om råd inför en resa till sin hemtrakt. Tsangnyön svarade med denna sång.

Fader, du som känner de tre tiderna

och kärleksfullt vårdar de sex klasserna av kännande varelser, som vore de dina egna barn.

Din godhet kan inte återgäldas.

Jag bugar inför mästaren Rabjam!

Du yogi, Döndrub Rabsel, som reser hem, har inte skurit av längtan efter ditt hemland.

Om du måste resa till varje pris, ska jag, yogin, sjunga en sång med instruktioner inför din resa.

Jag ber dig att lyssna till denna sång. Om du utövar utan att glömma dess budskap kommer du att förverkliga din egen och andras mening, både nu och i framtiden.

Utöva därför utan att glömma sångens budskap!

Så länge du inte bär döden i ditt hjärta, förändrar inte de buddhistiska lärosystemen sinnet.

Det räcker inte att du klär dig i gula kläder och rakar ditt huvud.

Uppmärksamma döden helhjärtat, ber jag dig!

När du helhjärtat uppmärksammat döden, och uppnått denna människokropp, med friheter och möjligheter, så svår att uppnå, 
finns ingen tid för det här livets angelägenheter.

Utöva flitigt och utan distraktion, ber jag dig!

Utan medvetenhet om bristerna i tillvarons kretslopp, överväldigas dharmautövaren av de åtta världsliga angelägenheterna.

Det är svårt att uthärda de lägre världarnas lidanden.

Var alltid ödmjuk, ber jag dig!

All lycka och allt lidande i detta liv

är orsakat av goda och dåliga handlingar i tidigare liv.

Om du önskar uppnå lycka och frihet från lidande här och nu, avstå från dåliga handlingar och utöva goda handlingar!

Förstå vikten av att undvika också till synes små negativa handlingar,

och se till att utföra också mycket små positiva handlingar.

Nedlåt dig inte till att utföra grova dåliga handlingar!

Då bringar du olycka över dig själv.

Om du studerar och reflekterar

över sūtrorna och tantrorna,

och mediterar i avlägsna bergsområden,

med själviska motiv,

lurar du visserligen de dumma,

men du väcker de segerrikas avsky.

Tillägna därför alla goda handlingar som du utför

de sex kategorierna av varelser,

så att de uppnår såväl orsaken till som resultatet av

både den tillfälliga och slutgiltiga lyckan och välbefinnandet.

Allt detta är viktigt för den oerfarne utövaren.

Nu ska jag sjunga om den djupa meningen

och förklara min insikt om

synsättet, meditationen, handlingssättet, grunden, vägen och frukten.

Synsättet innebär att inte intellektualisera.

Att intellektualisera det djupa synsättet

tillhör logikernas domäner. 
Men för mig som har förstått vad synsättet innebär finns varken djup eller frånvaro av djup.

Vila i synsättet när du mediterar.

Jag vet varken hur man är okoncentrerad eller hårt koncentrerad, att vara fokuserad men inte spänd är meditationens kännetecken. ${ }^{223}$

En meditationsutövare är fulländad när allt framstår som meditation.

Låt handlingssättet förenas med meditationen.

Hänge dig inte åt ett handlingssätt

med dina tre portars fyra aktiviteter, ${ }^{224}$

vars ursprung är konstruerat.

Utan låt allt uppstå naturligt.

Grunden, den naturliga och allomfattande dharmakāya, saknar i själva verket uppenbar orsak.

Förstå att alla fenomen, saṃsāra såväl som nirvāṇa, i grunden är dharmakāyas naturliga uttryck.

Vägen kännetecknas av att avstå från negativa handlingar och utöva goda handlingar.

Den fullbordas i grundmedvetandets natur, alltings innersta väsen.

Frukten av att ha tränat denna väg är att du förstår din egen natur, dharmatā.

Det som framträder upplöses i den oöverträffade tomheten. Detta är själva kärnpunkten, sök inte någon annanstans.

Låt detta bli instruktioner att bära med dig när du reser.

Evam! 


\section{DEN STORSLAGNA VAJRAS $\AA$ NGEN OM MAHĀMUDRĀS SYNSÄTT, MEDITATION, UPPFÖRANDE OCH RESULTAT}

Därefter vistades mästaren och hans lärjungar på de trettiotvå heliga platserna. Där utövade de med stor framgång, koncentrerat för att gagna andra. ${ }^{225}$

Dessa heliga platser är lika översållade av viraer och ḍākinīer som en öppen sesamskida är full av sesamfrön. Där finns den strålande Cakrasamvaras palats, och där offras kött och vin till Vajravārāhī. Där finns avlägset belägna och skrämmande platser som erbjuder en möjlighet att snabbt nå förverkligande - både det högsta och det vanliga. I dessa områden finns de storslagna begravningsplatserna, Sitavana och Ngampa Dradrog. ${ }^{226}$ Där talas allehanda språk och dialekter, och i gränstrakterna mellan $\mathrm{Do}^{227}$ och Tibet bor ett stort antal indiska och tibetanska kunskapsbärare. Dessa heliga och storslagna platser beskrivs i sūtror och tantror. Vid dessa platser förenas de tre sublima kanalerna i den inre kroppen. Bland de heliga platserna återfinns den begravningsplats som kallas Dharmas ursprung, och där finns den sublima platsen i söder, den strålande Tsari. I de övre områdena finns sinnets dharmapalats. Vid dessa platser uppstår mahāmudrā spontant även om vi inte mediterar.

Vid denna tidpunkt sade några yogier som deltog i en rituell offerfest till viraerna och ḍākinīerna: "Sjung en vajrasång till oss, en sång som manifesterar det högsta, med utgångspunkt i auktoritativa skrifter."

Som svar på deras önskan sjöng Tsangnyön den storslagna vajrasången, dohāsången som bär namnet "Insikten om den yttersta meningens åska, en introduktion till mahāmudrās synsätt, meditation, uppförande och resultat".

Sinnet är till sitt innersta väsen tomhet, bortom ord. ${ }^{228}$ Ändå uppenbarar det sig obehindrat på allehanda sätt. Jag bugar mig inför mästaren, Rabjam, likt solen och månen skingrar du okunnighetens mörker, det dualistiska fastklängandet. 
Jag, en yogi som känner djup tacksamhet gentemot kagyumästarna,

ska kärleksfullt ge er innerliga råd, lyckosamma lärjungar.

Dessa råd grundar sig i mina erfarenheter av den yttersta meningen,

det naturliga tillståndet.

Buga först, lyssna och praktisera därefter med tillit!

Det egna sinnet är rent från första början;

ni kan aldrig förlora det,

det går inte heller att fjättra det.

Ni som önskar uppnå frihet och renhet, sök inte efter sinnet utanför er själva.

Detta vore som att leka med en orm, eller som att släcka sin törst genom saltvatten.

Sluta söka efter sinnet utanför er själva

då det motverkar de metoder som leder till insikt.

Att söka efter det som inte kan förloras

leder till åtskillnad.

Att önska befria den obundna naturen

leder till bundenhet.

Att rengöra förorenar det ursprungligt rena.

Att gripa efter jag och annat leder till villfarelse.

Att söka i det yttre döljer det som finns i det inre.

Att hålla fast vid två när essensen är en

leder till åtskillnad.

Det finns de som mediterar på tomheten

som vore den skild från det som framträder.

Det finns de som särskiljer

essensen från det som uppstår.

Det finns de som tror att nirvāna

uppnås efter att de tagit avstånd från saṃsāra.

Det finns också de som tror att visdomen, bortom alla begrepp, får tankeverksamheten att upphöra.

När barnen får höra talas om sådana missuppfattningar, börjar de småle. 
Även de som har insikt småskrattar försiktigt.

Bägge skrattar på ett och samma vis.

Också de som har visdomens öga skrattar i hemlighet.

Det obundna sinnets natur är tomhet, klarhet och spontan närvaro.

Detta sinne fjättras av den snara som är önskan om befrielse och av det begär som griper efter det som framträder.

Stämpla inte med sigillet som befäster uppdelningen i subjekt och objekt

på den hårda knut som kännetecknar tillkrånglade metoder för befrielse!

Om ni har förmågan att vara obundna upplöses snaran, knuten och sigillet som fjättrar er.

Vid denna tidpunkt framträder de sammansatta och mångfasetterade företeelserna som icke-meditationen, fri från distraktion.

Då försvinner det gift som gör allt till objekt och därmed även meditativa hinder av olika slag.

Barnets enkelhet går förlorad i det komplicerade sinnet.

Medan den klokes komplicerade sinnes vågor löses upp i havet. Efter att ha skådat essensen blir vi fria från det tillkrånglade sinnets fyra felaktiga tolkningar av tillvaron. ${ }^{229}$ Yogin agerar inte över huvud taget.

Den sanna meningen framträder på en mängd olika sätt, inte enbart på ett sätt.

Om ni inte utövar fokuserat med kropp, tal och sinne, när ni förlitat er på en lama som är bärare av traditionen och har erfarenheter, vilseleds ni av logikernas bubbellika förståelse.

Logikernas synsätt liknar hantverkarens vattenflaska. Inte ens den som tillverkat den kan se dess insida.

Logikernas meditation liknar reflektionen i en spegel. De glömmer bort orden när de uttalats och kan inte meditera. ${ }^{230}$ 
Logikernas uppförande liknar en nygift bruds.

Måna om sitt yttre uppträder de varligt.

Logikernas resultat liknar en vas av lera som ännu inte bränts.

Genom de dåliga omständigheternas flod förstörs det med säkerhet.

De inre upplevelserna är bortom tekniska benämningar.

De uppstår på grund av de muntliga instruktionerna.

Vad yogin än gör ${ }^{231}$ bevarar han alltid dessa upplevelser, såväl i sitt yttre uppförande som i sitt inre.

Yogins synsätt liknar sonen som upprätthåller sin faders hus.

Yogins meditation är som himlens mittpunkt.

Fri från referenspunkter

rubbas den inte av något.

Yogins uppförande är som tidens gång.

Det går inte att stoppa resultatet av hans insikt, eftersom det skapas av sig självt.

Yogins resultat är som en önskeuppfyllande juvel.

Bortom såväl saṃsāras som nirvāṇas begreppsmässighet uppstår allt som han behöver och önskar.

Därför förverkligar alla de som har tillit, ihärdighet och visdom resultatet i enlighet med skrifternas ord.

Dessa, mina innerliga och väl formulerade råd, fullbordar resultatet: det naturliga tillståndet. ${ }^{232}$

Även om en skicklig läkare ser medicin ligga på marken blir medicinen till ett botemedel först då den ges till en person som är sjuk.

Även om en skicklig andlig lärare har kunskap om olika instruktioner är det endast just de muntliga instruktioner som mottagaren har kapacitet att förstå som den andlige läraren ska lära ut. 
Dessa djupa instruktioner

är den främsta medicinen för en sjuk person

med potential att uppnå omedelbar insikt, men ett gift för den som kommer till insikt gradvis och följer förtjänsternas väg.

Sålunda är det en lära

som de som följer den gradvisa utvecklingens väg ska avstå från.

Men för dem som har potential till omedelbar insikt är det den främsta vägen.

Såsom en kärleksfull mor tar hand om sin ende son genom att gradvis förse honom med mat, kläder, smycken och sådant han behöver för sina dagliga aktiviteter, ska den främste andlige mentorn vägleda lärjungarna på ett sätt som får dem att göra framsteg utifrån deras respektive konstitution och erfarenheter.

Evam!

Denna sång gjorde att många av de lyckosamma lärjungarna nådde mognad och befrielse. 


\section{INSTRUKTIONER TILL HJÄRTESONEN RINCHEN PALSANG INFÖR HANS RESA TILL TSARI}

Därefter färdades mästaren och lärjungarna genom centrala Tibet. Efter att ha anlänt till södra Latö tryckte Tsangnyön och hans lärjungar upp vördade Jetsun Shepa Dorjes (Milarepas) biografi och sångsamling. De gjorde detta för att gagna andra och texterna trycktes i Kristallgrottan i Nedum. När cirka två tredjedelar av arbetet var färdigt var det dags för yogi Tashi Rinchen Palsangpo att bege sig till den mycket heliga platsen Tsari för att utöva för andras skull. Rinchen Palsangpo var den av Tsangnyöns närmaste lärjungar som först nådde förverkligande. ${ }^{233}$ Innan han gav sig av sjöng Tsangnyön denna sång med muntliga instruktioner:

Med de tre portarna fyllda av respekt

bugar och lovprisar

alla trofasta söner i kunskapsbärarnas tradition

inför fädernas, de heliga kagyulamornas, fötter.

Rinchen Pal, du är som mitt hjärta.

Detta är mina innerliga råd inför din resa.

Glöm dem inte utan tänk på dem regelbundet!

När du vandrar land och rike kring, omvandla de fem objekten som behagar sinnena till offergåvor, genomskåda det som förleder dig och låt, med stor vaksamhet, detta bli en del av vägen.

När konstgjord respekt vars urspung är Māra uppstår inom dig, och ditt högmod samt din själviskhet ökar, slå då kraftfullt tillbaka begäret såväl i tanke som i handling.

När du vandrar över skräckinjagande begravningsplatser och begravningsplatsens herre hemsöker dig, ${ }^{234}$ inse då att han inte är något annat än ditt eget sinne!

När du vandrar ensam i ensliga bergsområden och insikter, goda egenskaper 
samt tecken på framgångsrik utövning uppstår, ${ }^{235}$ inse då att detta uppstår på grund av lamans godhet.

När lärjungar med goda förutsättningar samlas runt dig, beror detta med säkerhet på att ni har goda karmiska förbindelser från tidigare liv.

Skänk dem mognad och befrielse genom rituella invigningar och muntliga instruktioner!

Ogynnsamma omständigheter och hinder som uppstår är uppmaningar till att utöva godhet som kommer från mig. Var medveten om detta och be till mig om och om igen!

O son som är som mitt eget hjärta.

På grund av min stora kärlek beskyddar jag, din andlige fader, dig ständigt.

Ge dig nu av till den heliga platsen Tsari och meditera!

Må du uppnå fulländning i tanke och handling. I detta och i alla dina kommande liv!

Lamor, yidam och beskyddare, beskydda och var aldrig separerade från Rinchen Palsang! Må kagyuläran spridas!

Evam! ! 


\section{SÅNGERNA TILL KUNTU SANGMO}

När sedan tryckningen av biografin över Milarepa och Milarepas sångsamling var helt och hållet fullbordad flyttades träblocken till Maggrottan i Nyanang för att förvaras där.

Efter detta vistades den vördade mästaren Tsangnyön och lärjungarna i Lachis avlägset belägna snöhöljda bergsområde för att med total koncentration utöva för andras nytta.

Den heliga platsen Lachi är också känd under namnet Godāvarī och är en av Cakrasaṃvaras tjugofyra heliga platser. Godāvarī representerar det vänstra örat i Cakrasaṃvaras subtila kropp. ${ }^{236}$ Platsen är belägen på gränsen mellan Nepal och Tibet, långt från städernas jäkt, bland skiffer och snö och i omgivningar som är täckta av moln och dimma. Det är en plats där upphöjda indiska asketer bor och vistas, en samlingsplats för viraer och dākinīer, ett centrum för förverkligandets dharmahjul, en juvel som upprätthåller Buddhas lära, en underbar grundsten till den utövande traditionens palats, masten på kagyulärans stora skepp, en helig plats där meditationen av egen kraft blir allt starkare.

Vid detta tillfälle sade Tsangnyön till modern, Kuntu Sangmo: "Flicka, var fullständigt uppmärksam på det som är till nytta, nu och i framtiden!"

Då bad Kuntu Sangmo om en instruktion som frammanar uppmärksamhet. Mästaren svarade:

Den som vill frammana uppmärksamhet

ska meditera på att döden kan komma när som helst.

När dödens ofrånkomlighet uppmärksammas, kommer fliten av sig själv.

Men för den som är distraherad av lättja och ouppmärksamhet, leder till och med den ordinerades gula klädnad till dålig karma.

Den som skapar sitt eget lidande kastar sig, här och nu, in i en eld. 
Men den som önskar varaktig lycka och välbefinnande, fullbordar, i detta liv, det som gagnar honom själv och andra.

Förstå att fienden är att låta sig förledas av detta livs angelägenheter!

Detta är din faders innersta råd, bevara dem ständigt inom dig!

Bevara dem alltid i sinnet på detta sätt, Sangmo!

Evam!̣! ${ }^{237}$

Återigen frågade modern, Kuntu Sangmo: "Fastän meditationen under uppbyggandets meditationsfas ska vara som en regnbåge, upplever jag meditationsobjektet som något konkret och påtagligt. Fastän meditationen under fullbordandets stadium ska vara som himlen, upplever jag ett fasthållande vid saker och ting. Var god och ge mig en undervisning som hjälper mig med detta." Som svar sade mästaren:

Namo guru!

Som svar på en flickas frågor har jag detta att säga:

Meditationsgudomligheten är som en regnbåge.

Men om du inte förstår att den som mediterar är gudomligheten, hur kan då något annat än det konkreta och påtagliga uppstå?

Det som uppstår är ursprungligen tom form.

Om du vill att detta ska framträda som den rena gudomens kropp,

krossa då omedelbart tudelningen

mellan det som uppstår och tomheten!

Då visar sig gudomlighetens verkliga ansikte.

När du ser dess verkliga ansikte,

finns inte längre någonting att meditera på.

Du missförstår det himmelska fullbordandets stadium

om du i din meditation särskiljer tomheten

från det som framträder,

det vill säga tomheten från gudomlighetens illusoriska kropp. 
Sluta undertrycka eller frammana sådant som framträder på grund av olika omständigheter, oavsett vad det är! Se ditt eget ansikte!

Låt meditationen och den som mediterar, det som förnekas och det som bekräftas, smälta samman och låt bli att intellektualisera!

Ej heller handlar det om att inte meditera, liksom en ungdoms upplevelser av lycka är det något som inte kan uttryckas i ord.

Gör uppbyggandets och fullbordandets meditationsfaser till ett.

Glöm inte detta utan behåll det ständigt i sinnet!

Evam! $!^{238}$

Därpå sade Kuntu Sangmo: "Förklara också hur vi ska utöva under och mellan meditationsperioderna. Undervisa också om orsak och verkan.” Som svar sjöng Tsangnyön denna sång:

Jag bugar inför de upphöjda lärarna!

Det inneboende sinnets natur är till sitt ursprung bortom konstlade begränsningar. Subjekt-objekt-uppdelningens allehanda fenomen framträder, men saknar egen natur.

När du utövar meditation, måste du vara helt närvarande i enkelhetens tillstånd.

När du bär med dig din utövning mellan meditationsperioderna, måste du uppmärksamma att det som framträder är tomhet.

Orsak och verkan är förvisso tomhet till sitt väsen, men låt dig inte luras av den relativa verkligheten i din förståelse av orsak och verkan.

Vid alla tillfällen och vid varje tidpunkt måste du avstå från negativa handlingar och utöva goda handlingar. 
TSANGNYÖN HERUKAS SÅNGER

Det vore mycket bra om du utövade på detta sätt.

Låt detta belysa hur du ska meditera!

Evam! $!^{239}$ 


\section{DHARMAINSTRUKTIONER TILL HJÄRTESONEN CHÖCHOK PALSANG INFÖR HANS RESA}

Efter att ha utövat för andras väl på denna plats (i Lachi) begav sig mästaren och lärjungarna till Chuwar. ${ }^{240}$ På vägen dit färdades de över flera större och mindre snöklädda berg och genom bergspass.

Chuwar ligger bland skiffer och snö. Långt från städernas jäkt och stress är det omgivet av moln och dimma. Det är en skrämmande plats där de åtta klasserna av våldsamma demoner samlas. Ovanför Luigyalpo Dungtra Nepe Potrang, ${ }^{241}$ i de övre och lägre trånga passagerna, vandrar Rāhu-Vișṇu. ${ }^{242}$ Chuwar ligger öster om den dyrbara klippan som liknar ett majestätiskt lejon, framför Dragmarpo Dongsum. ${ }^{243}$ Det ligger på vänster sida om Khanglha Mengyalmo, ${ }^{244}$ nedanför gyllene moln och blåsvarta bergstoppar. Där finns den blåsiga flodbanken, förverkligandets flod, Lotoha. I Chuwar är himlen och jorden så beskaffade att dharma uppstår spontant. Chuwar är en plats där upphöjda indiska asketer vistas. Det är den allra heligaste platsen, där den mäktiga Milarepa uppnådde fullkomligt uppvaknande under ett enda liv och i en enda kropp. ${ }^{245}$ Det är också en ytterst enslig plats, känd som Nirmāṇakāyapalatset Chuwar.

När Tsangnyön och hans lärjungar vistades vid eremitboningen Ganden i Chuwar förberedde sig hjärtesonen Chöchok Palsang på att utöva för andras skull i centrala Tibet. ${ }^{246}$ Tsangnyön sjöng då sången om hur man regerar, instruktioner inför resan.

Namo guru!

Jag bugar mig inför dig fader, nirmāṇakāya, allestädes närvarande herre!

Skänk mig och alla dina hängivna lärjungar välsignelse så att vi fullbordar det som gagnar oss själva och andra!

Jag, en slöfock som planlöst strövar runt på begravningsplatserna, ska sjunga en sång med innerliga instruktioner till dig, yogi Chöchok Palsang, inför din resa. Glöm dem inte, utan bevara dem i ditt hjärtas djup! 
Son, utövar du de upphöjdas lära på riktigt eller ej?247 Om du verkligen utövar de upphöjdas lära från hjärtat finns inget annat att utöva än att ståndaktigt utplåna jagbundenheten.

Denna jagbundenhetens vilseledande demon har, genom sina många skickligt utförda bedrägliga manifestationer, försatt dig i lidande i begynnelselös saṃsāra, i dina tidigare liv fram till nu.

Generellt är det just denna bundenhet som visar skillnaden mellan en person som utövar den heliga dharma och en världslig person.

Om du ägnar stor flit åt att förverkliga det som enbart har med detta liv att göra - i allt du gör, vad det än är och dyrkar jagbundenhetens demon, kallas du en världslig, saṃsārisk person.

Men kuvar du fienden, jagbundenheten - i allt du gör, vad det än är för att i dina framtida liv förverkliga det som gagnar dig själv och andra, kallas du en utövare av de upphöjdas heliga lära.

Eftersom det är på detta sätt, ska jag, din far - som befinner mig i saṃsāras och nirvāṇas gränsland och vet hur man skär av roten till dem båda, och har uppnått det slutliga målet förklara för dig, hängivne son Chöchok - som önskar kuva fienden, jagbundenheten, men inte kan hantera sinnet hur man skär av roten till jagbundenhetens demoniska handlingar. 
Någon Māra, jagbundenhetens onda ande, med mörk motbjudande gestalt och vapen i sina händer, finns inte.

Trots detta får den dig att vända dig bort från det slutgiltiga oöverträffade uppvaknandets nivåer och vägar.

Den får dig att förverkliga det villkorliga och tillfälliga välståndet och den leder dig till de tre lägre världarna.

Förutom detta förhåller det sig på följande sätt med denna typ av förverkligande: klärvoajans, mirakulösa förmågor, välsignelse, kraftfullt tal och så vidare, som är orent och färgat av de åtta världsliga saṃsāriska angelägenheterna, kan förvisso leda till berömmelse, lovord och rikedom, men du bedras av dessa fyra så kallade fördelaktiga omständigheter. ${ }^{248}$

Ett tecken på att du blir bedragen är att du inte står ut med andras välstånd och är fylld av högmod, arrogans och självupptagenhet.

När även de forna mästarna avskydde jagbundenheten, behöver man då ens nämna hur vanliga människor med sämre förutsättningar ska förhålla sig? Som nämnts finns det en mängd olika sätt genom vilka du bedras av jagbundenheten. Iakttag därför yttersta försiktighet!

Alla rikedomar, handlingar och tankar som är inriktade mot detta liv är tveklöst Māras villfarelser. Därför, eftersom du befinner dig vid ett mycket farligt vägskäl, samla ihop en armé av kagyutraditionens medkänsla!

Om du nu med din dyrbara människokropp inte övervinner din jagbundenhet och dör, i så fall, 
i samma ögonblick som onda tankar uppstår,

vänta i meditationens och postmeditationens trånga passage; och i samma ögonblick som minnen från detta liv uppstår, håll, med obruten närvaro, fast vid insikten om sinnets natur!

Håll ihärdigt och utan rädsla fast vid dina samayaåtaganden! Förkasta och avsluta den världsliga vägen!

Straffa fienden - jagbundenheten - i enlighet med lagen på följande sätt:

Fånga in den med avsmaken och avståndstagandets lasso! Fjättra den med stillhetsoch insiktsmeditationens järnkedjor!

För den till de ensliga eremitagens rättegångssal. Döm den utifrån sanningen i orsak och verkan!

Lås in den i den stabila meditationens fängelsehåla! Prygla den med käppen: postmeditationens illusion!

Hugg av dess fötter som går efter sinnesnjutningar! Skär av dess händer som utför negativa handlingar!

Peta ut dess ögon som ser andras fel!

Skär av dess öron som lyssnar till det orena sinnets röst!

Hugg av dess näsa som nosar efter de osunda tankarnas vind! Dra ut dess tunga som prisar sig själv och talar illa om andra!

Flå dess kropp som är hyckleri!

Skär av jagbundenhetens stora kroppspulsåder!

Till slut, när du på detta sätt har avrättat den ökände dödsfienden, efter ett oändligt antal liv i tillvarons kretslopp, kasta då också ner jagbundenhetens - fiendens likrester i den stora gränslöshetens avgrund!

Begrav den i jorden som är den fundamentala likheten av saṃsāra och nirvāṇa! 
Tvätta den i medkänslans vatten

som är att hålla andra mer kära än dig själv!

Bränn upp den i kunskapens och visdomens eld!

Låt dess aska blåsa bort i dharmatās vind!

Det är på detta sätt du blir kvitt den hatiska fienden, jagbundenheten!

$\mathrm{Nu}$ ska jag förklara hur du ska utöva om du lever bland nära och kära:

Den som önskar uppnå uppvaknande i detta liv, men är drabbad av denna världs ogynnsamma omständigheter och saknar goda och gynnsamma omständigheter, en sådan person som har förtjänster, kan tack vare de tre juvelernas medkänsla, även om han eller hon överväldigas helt av ogynnsamma omständigheter, hantera dessa plötsliga ogynnsamma omständigheter och rena djupt rotade skymmande slöjor, skadliga handlingar och deras konsekvenser.

Först, fylld av avsmak och avståndstagande, börja utöva den heliga dharma.

Därefter, uppmuntra utövningen och förinta Māras bedrägliga lek.

Slutligen, omständigheterna och det som ska förverkligas: Utövningen resulterar i att de fyra buddhakropparna uppenbarar sig. De ogynnsamma omständigheterna blir då vägen och det yttersta målet förverkligas i detta liv.

Dessa lagar om hur man besegrar fienden och hjälper vänner faller inte inom den världsliga konungens område. Dessa lagar står över de världsliga lagarna, sådana är mina, den sanna konungens, lagar. 
Son, när du regerar över den inre vägens kungadöme, finns ingen annan metod än just denna lag.

Med hjälp av denna lag fullbordas det som gagnar dig själv och andra.

Jag har gett dessa goda råd, och utifrån min godhet och kunskap har jag formulerat detta svar.

Ge den kontinuerliga utövningen som en offergåva!

Be utan skenhelighet, och tillägna alla varelser förtjänsten!

Från och med nu och fram tills du uppnår uppvaknandet, utan att bry dig om ditt eget välbefinnande, använd din kropp, ditt tal och ditt sinne till att tjäna andra!

När du verkligen ger bort allt det förtjänstfulla och lyckosamma i hela fenomvärlden som en offergåva, förverkligas dharmakāya, för ditt yttersta väl.

Genom detta blir du förmögen att fullborda andras obegränsade välgång.

Även om jag skulle dö, har jag, en dåre som vandrar bland bergen, inget annat testamente än detta!

Detta är mina innerliga råd och de är värda att lyssna till.

Förstå dem och utöva dem sedan!

Evam! $!^{249}$

Så sjöng Tsangnyön, och hjärtesonen (Chöchok Palsang) blev en person som fick det att dagas för den utövande traditionens läror i centrala Tibet. 


\section{EN SÅNG SOM SAMMANFATTAR STADIERNA OCH VÄGARNA TILL MÖNDZE TOGDEN}

Vid ett annat tillfälle mottog Tsangnyön ett brev från hjärtesonen Möndze Togdenpa. ${ }^{250}$ Brevet innehöll en önskan om en sång som förklarar hur man förenar den omedelbara insikten om sinnet med den gradvisa utövningen av de fem vägarna och de tretton stadierna. ${ }^{251}$ Som svar sjöng Tsangnyön denna sång som sammanfattar stadierna och vägarna:

Fylld av vördnad i kropp, tal och sinne prisar och bugar jag inför den vredgade fadern, dharmaherren, Rabjam! ${ }^{252}$

Som svar på din fråga, käre son, Kunga Legsang, ${ }^{253}$

följer här en spontan sång.

Bevara den i sinnet med odelad hängivenhet och begrunda den väl!

Utöva därefter dess mening utan avbrott!

Sinnet är ofött och saknar egen oberoende natur, därför finns inga stadier eller vägar att fullborda.

Eftersom dess naturliga uttryck framträder obehindrat är allting sinnets manifestationer.

Sluta därför dela in den omedelbara insikten i stadier och vägar!

Ackumulerandets väg är att förstå att det som framträder är tomhet.

Tillämpningens väg är att lära sig se tomheten i det som framträder.

Insiktens väg är att förstå deras ursprungliga oskiljaktighet.

Meditationens väg är att utöva i enlighet med insikten.

Vägen bortom lärande är när du saknar orsak till andliga framsteg,

då är du fri från indelningar angående vad som ska ges upp och vad som ska utföras. ${ }^{254}$ 
Sluta benämna glädjen att se ditt innersta väsen som den högsta glädjens stadium! ${ }^{255}$

Det obefläckade stadiet är inget annat än ${ }^{256}$ friheten från de brister som uppdelningen i subjekt och objekt medför.

Det lysande stadiet är inget annat än ${ }^{257}$ sinnets inneboende klarhet.

Det strålande stadiet är inget annat än ${ }^{258}$ förmågan att gagna andra.

Det svåruppnådda stadiet är inget annat än ${ }^{259}$ friheten från förmörkande slöjor.

Det klart manifesterade stadiet är inget annat än ${ }^{260}$ sinnets rymd och insikt i förening. Det långtgående stadiet är inget annat än ${ }^{261}$ att sluta hålla fast vid det eländiga klängandet. Det orubbliga stadiet är inget annat än ${ }^{262}$ att uppnå stabila insikter och erfarenheter. Den enastående insiktens stadium är inget annat än ${ }^{263}$ att förvärva alla de goda egenskaperna.

Lärans molns stadium är inget annat än ${ }^{264}$ att spontant uppfylla önskningarna.

Det allomfattande ljusets stadium är inget annat än ${ }^{265}$ att vara fri från saṃsāras och nirvānas mörker. Det lotusförsedda stadiet är inget annat än ${ }^{266}$ att vara skyddad från saṃsāras och nirvāṇas fasor. ${ }^{267}$ Vajradharas stadium - det fullkomliga uppvaknandet är inget annat än ${ }^{268}$

friheten från fel och brister samt det fullständiga uppnåendet av alla goda egenskaper.

Sålunda är allt som framträder och existerar, alla utsagor och alla ljud sinnets naturliga lekfulla uttryck.

Dessa uttryck är obehindrade och saknar oberoende existens.

Om du inte från första början skurit av klängandet till det som inte är verkligt existerande, till det drömlika och illusoriska, 
förlorar du din frihet och blir slav under klängandet.

Därför, son, vila i ett tillstånd där du inte klänger fast vid någonting!

När du full av klarhet befinner dig i ett tillstånd utan fastklängande,

har solen gått upp på himlen

och skingrat det anhopade mörkret.

Efter att mörkret har lösts upp i sig självt, framträder allt i sin strålande klarhet.

Då fullbordas det som framträder, vägarna, stadierna och alla goda egenskaper

i sin inneboende klarhet - den stora sällheten.

Då har du uppnått det trettonde stadiet - Vajradharas nivå. Hys inget tvivel om detta!

Och var ihärdig när du utövar uppbyggandets och fullbordandets meditationsfaser!

Utöver detta har jag följande innerliga råd att ge dig:

Om du låter dig själv bli distraherad när du lyssnar, reflekterar och mediterar, är även allehanda budbärare med fina namn och vackra ord inget annat än den så kallade Māra.

Låt därför inget avbryta din utövning!

Om du saknar medkänsla och förmågan att hålla andra mer kära än dig själv, är även en god förståelse av tomheten inget annat än det nihilistiska synsättet.

Om medkänslans flod inte strömmar genom ditt sinne och den upphöjda godheten förväxlas med falsk godhet bedrar du dig själv och andra.

Oavsett vad som uppstår inom dig när du utövar, såsom vita och röda ljusfenomen, låt dig inte distraheras utan utöva mahāmudrā! 
$\mathrm{O}$, du käre son, Kunga Legsang.

Om jag skulle dö

har jag inget annat testamente att ge dig än detta.

Om vi skulle mötas igen

har jag inga andra innerliga råd att ge dig än dessa.

Vänd detta livets angelägenheter ryggen

och vandra kontinuerligt runt bland ensliga bergseremitage.

Utöva i enlighet med de tre samayaåtagandenas mening,

utan att tvivla på dig själv!

Och följ kagyulamornas levnadsexempel!

Evam! $!^{269}$

Genom denna sång skingrades denne hjärtesons tvivel och osäkerhet. 


\section{EN SÅG MED INSTRUKTIONER TILL KUNG SHERAB PALSANG}

Därefter begav sig mästaren och lärjungarna till Svayambhū för att fullborda vitmålandet av stūpan. ${ }^{270}$ Resan gick via Gungtangs huvudstad. När de var där uppfyllde Tsangnyön kungligheternas - faderns och sönernas - önskemål, genom att ge dem rituella invigningar och undervisning. Vid denna tidpunkt bad kung Sherab Palsang om en sång som gagnar sinnet och vars innehåll är lätt att förstå och tillämpa. ${ }^{271}$ Som svar sjöng Tsangnyön denna sång med muntliga instruktioner:

Namo guru!

$\mathrm{O}$, gudomlige son, härskare, Sherab $\mathrm{De},{ }^{272}$

du säger att du behöver den heliga läran som gagnar sinnet.

Begrunda då detta:

Att se en stjärna på ljusa dagen

är lika svårt och ovanligt som att finna en dyrbar människokropp.

Lika säkert som att den uppgående solen också går ner är det att den som en gång har fötts också dör.

Begrunda detta!

Lika säkert som att en rättfärdig konung bestraffar brott är orsak och verkan i sanning ofrånkomliga.

Begrunda detta!

Lika säkert som att vi inte står ut med den minsta krämpa är bristerna i tillvarons kretslopp outhärdliga.

Begrunda detta!

$\mathrm{Nu}$ ska jag förklara den huvudsakliga utövningen.

Även om det verkar som om många utövar

den heliga upphöjda läran, ${ }^{273}$

är det endast ett fåtal som utövar helhjärtat.

Utöva därför den upphöjda läran helhjärtat

- besegra jagbundenhetens demon! 
Om ditt sinne har vänt sig till läran finns det ingenting som inte är den heliga dharma.

På samma sätt som all mat smakar gott för en hungrande, har alla företeelser en djup mening för den som tagit avstånd från tillvarons kretslopp. Men den som inte i sanning tagit avstånd från tillvarons kretslopp i sitt hjärta, utan endast antar den yttre formen av en dharmautövare och låtsas vara god för att bli känd och respekterad, visar sig vid närmare granskning bedra såväl sig själv som alla andra.

Om kungasonen önskar utöva den osvikliga heliga läran, upprätthåll då rikets lagar i enlighet med den heliga läran! Även om du är fullt upptagen med att utföra olika ritualer och ceremonier, är det svårt att ha kontroll över sinnet när du dör. Därför, son, se din egen medfödda natur!

Även om det finns många som har kunskap om de filosofiska synsätten, som har fått muntliga instruktioner och som har ett gott uppförande, ${ }^{274}$

är det få som direkt ser det obefläckade sinnets verkliga natur. Därför, identifiera och iaktta det som plötsligt uppstår i sinnet!

Iakttagandet, den som iakttar och det som iakttas är oskiljaktiga. Son, vila i enkelhetens tillstånd!

När något uppstår i sinnet och du inte längre kan vila i sinnets natur,

kämpa då inte emot, utan låt det vara!

Genom att låta det som uppstår i sinnet vara, återvänder du till sinnets naturliga tillstånd. 
Detta är den underbara yttersta sanningen,

kungason, som ett resultat av att du har insett den yttersta sanningen,

beskydda de kännande varelserna med din visdom och medkänsla!

Evam!

Sålunda sjöng Tsangnyön och sången var till mycket stor nytta för kungens sinne. ${ }^{275}$ 
Därefter tillbringade den vördade som smyckar sig med benornament och hans lärjungar tre år i Kailash - den heliga plats som hyser den vita lejonhövdade gudinnans kropp. Där utövade de för att gagna andra. Kailash är en plats som de åtta klasserna av fasansfulla demoner offrar till. ${ }^{276}$ Kailash hyllas också i många av den upphöjdes sūtror och tantror. Kailash är världens navel, Shivas hemvist samt den strålande Cakrasamvvaras palats. Bland de tjugofyra heliga platserna är Kailash den som är Himālaya. Där finns de fyra stora flodernas källa samt Nāgakungen Anavataptas palats. ${ }^{277}$ Där har sjön Manasarovar sin upprinnelse och den gamle ärevördige munken Angiraja sin boning. Kailash är alla bergs snöhöljda konung.

När Tsangnyön vistades där komponerade han en sång som bestod av femton muntliga instruktioner om hur man ska leva sitt liv. Sången skrev han till härskarinnan av Menkabtö, Kunga Gyalmo. Dessa instruktioner nedtecknades i ett brev. ${ }^{278}$

\section{Namo guru!}

Här följer mina innerliga råd till hjälp för den hängivna Kunga Gyalmos sinne.

När du nu uppnått en dyrbar mänsklig kropp är det mitt innerliga råd att du använder den meningsfullt.

Det är mitt innerliga råd att du nu lär dig skilja mellan klokhet och dumhet och förverkligar den stora meningen.

Negativa handlingar skadar dig nu och i framtiden.

Det är mitt innerliga råd att du helt och hållet avstår från att utföra dem.

Goda handlingar är till nytta i alla tider.

Det är mitt innerliga råd att du utför dem med stor flit. 
Den bästa underhållningen är att betrakta det egna sinnet. Det är mitt innerliga råd att du tittar utan distraktion.

Jag har dessutom följande innerliga råd till dig:

När du behagar de tre juvelerna är du en vacker kvinna.

När du har ädel rikedom är du en rik kvinna. ${ }^{279}$

När du är utsmyckad med tro är du en elegant kvinna.

När du har medkänsla är du en ädel kvinna.

När du har flit är du en klok kvinna.

När du har visdom är du en förnäm kvinna.

När du förstår tillvarons natur är du en lärd kvinna.

När du övervunnit jagbundenheten är du en hjältinna.

Om du lever ditt liv på detta sätt

blir din mänskliga kropp meningsfull.

Utöva på detta sätt,

då det är till nytta för dig själv och för alla andra.

Evam! $!^{280}$

Genom denna sång uppnådde härskarinnan outplånlig tro. 


\section{FYRA VAJRASTROFER TILL LOPÖN JETSUN}

Därefter begav sig mästaren, yogiernas herre, och hans lärjungar till nirmānakāyapalatset Chuwar. Efter att de stannat där i fem år och utövat för andras skull, bad kungen av Nepal och den mäktige guden Gaṇapati att Tsangnyön skulle renovera Svayambhūstūpan i Nepal. ${ }^{281}$ Denna stūpa omnämns i profetiska avsnitt av Oxhornssūtran, i Mañjuśrīs rottantra, samt i profetior i många andra av den segerrikes texter. ${ }^{282}$ Gomasalagatastūpan är ett objekt som skapar förtjänst för alla kännande varelser och den är belägen i en lund som är full av olika enastående träd. ${ }^{283}$ Stūpan är byggd på order från tidigare buddhor.

Tidigt på morgonen, en dag efter att Tsangnyön anlänt till stūpan, offrade den mäktige guden Gaṇapati och den gudomlige snickaren följande sång till Tsangnyön. ${ }^{284}$ De sjöng unisont och framförde sången på det sätt som adelsmän i Nepal gör.

Hur underbart! O du högste emanationskropp!

$\mathrm{O}$ du ädle som förutspåtts av den segerrike!

För lärans och varelsernas skull

kommer vi att hjälpa dig renovera stūpan.

Vi lovar att du snabbt kommer att fullborda renoveringen.

Efter dessa ord försvann de bägge gudomligheterna. Därefter, vid ett tillfälle, sade den vördade mästaren:285 "Jag behöver en kortfattad dharmainstruktion med djup mening." Som svar sjöng Tsangnyön denna sång:

Namo guru!

Lyssna du, vördade guru, son!

I din meditation:

Låt sinnet vara bortom såväl saṃsāra som nirvāṇa!

I din postmeditation: ${ }^{286}$

Avstå från negativa handlingar och utöva goda handlingar!

Detta är vad dåtidens, nutidens och framtidens segerrika har lärt ut. 
ÖVERSÄTTNING AV TSANGPA HERUKAS SÅNGAMLING

Det är också vad jag, dåren, utövar.

Utöva på detta sätt även du!287

Sången väckte en oerhört stark övertygelse i den vördade mästarens sinne. 


\section{MANIS ANGEN SOM BESKRIVER HUR GENYEN SHENTAPUTRI BAD TSANGNYÖN RENOVERA SVAYAMBHŪ}

När sedan renoveringen var helt och hållet fullbordad, begav sig mästaren och hans lärjungar till Lajang. ${ }^{288}$ Vid platsen där avskedsceremonierna ${ }^{289}$ utfördes sjöng Tsangnyön denna maṇisång:

Oṃ maṇi padme hūṃ!

Säg inte att jag är någon jag inte är.

Jag är en son till kagyulamorna.

Jag är de tre heliga bergens snölejon.

Jag är herre över de åtta klasserna av demoner.

Jag är älskad av modergudinnor och ḍākinīer.

Jag, en galen yogi som vandrar land och rike kring,

sover på begravningsplatser

och slåss med vandrande lik.

När jag första gången målade stūpan vit

överlämnade Gaṇapati en dyrbar behållare

som var utsmyckad med smör

samt dess innehåll till mig.

Han sade att han skulle överlämna arbetare

för renoveringen av stūpan till mig.

Jag sade att jag inte kommer att fullborda detta projekt.

Han sade att jag kommer att klara av det

och att jag måste göra det vad som än händer.

Modlös sade jag att jag bävar inför denna uppgift.

På grund av dessa löften

fullbordades renoveringen av Svayambhūstūpan.

Om gudomliga väsen inte klarar av att utföra renoveringen,

hur ska då människor kunna göra det?

Gudar och människor som samlats här,

må vi mötas i ett framtida liv! ${ }^{290}$ 
Tsangnyöns sång fick skaran av nepaleser, tibetaner och människor från Nyishang som samlats där att känna en djup glädje. Fyllda av hängivenhet brast de i gråt, inte ett öga var torrt. 


\section{EN SÅNG TILL DHARMAKUNGEN DÖNYÖ DORJE: HUR MAN UPPRÄTTAR RÄTTFÄRDIGA LAGAR SOM ÄR I SAMKLANG MED L ÄRAN}

Mästaren och hans lärjungar begav sig därefter ännu en gång till nirmānakāyapalatset Chuwar. Där utövade de för andras skull i tre år.

Eftersom de flesta av Tsangnyöns handlingar var fullbordade, var det nu tid för hans uppgående i nirvāṇa. Dessutom, för att få karmiska förbindelser med många varelser, och på grund av kraften i hans önskan om en lämplig plats för nirvāṇa, förstod Tsangnyön att om han skulle dö i Rechungpuk i Yarlung, skulle detta vara till stor nytta för de kännande varelserna.

Tsangnyön färdades därför till de rena länderna Ü och Tsang, och när han passerade Nyetang undervisade han den mäktige härskaren som har den stora förtjänstens hjul, vars fälgar består av önskeböner och vars tusen ekrar är segerrika i alla riktningar. ${ }^{291}$ För denne kung, som beskyddar läran och vars namn är Dönyö Dorje, förklarade Tsangnyön kapitlet "Den kungliga lärda utläggningen, den gudomlige härskaren" som återfinns i Det sublima gyllene ljuset, sütrornas konung. ${ }^{292}$ I samband med detta sjöng Tsangnyön sången som visar hur man upprättar rättfärdiga lagar som är i samklang med läran.

Namo guru!

O kung, se i "Den kungliga lärda utläggningen, den gudomlige härskaren" som ingår i Det sublima gyllene ljuset, sūtrornas konung! Jag, yogin, ska förklara textens innebörd i enlighet med kungens insikt, som när solen skiner på snöberget och får det vita att framträda än tydligare.

När kapten Nyingje Chenpo dödade den svartsinnade förbrytaren var detta ett uttryck för den högsta dygden hos de ädla som följer 
den stora farkostens inställning och uppförande. ${ }^{293}$

Genom detta undkom femhundra köpmän döden. ${ }^{294}$

Fylld av omedelbar kärlek oskadliggjorde

Nyingje Chenpo den svartsinnade.

För att kunna göra detta var han tvungen

att, för ett ögonblick, agera våldsamt

mot den svartsinnade.

Därmed bröt han utan tvekan

mot sūtrafarkostens disciplin. ${ }^{295}$

Nyingje Chenpo begick också

den färde rotöverträdelsen

i den hemliga mantrans vajrafarkost. ${ }^{296}$

Genom att döda den svartsinnade

var han nämligen, för ett ögonblick,

tvungen att åsidosätta

sin kärlek mot en kännande varelse. ${ }^{297}$

Eftersom Nyingje Chenpo också

hyste omedelbar kärlek gentemot den svartsinnade, begick han den tionde rotöverträdelsen:

han hade ett vänskapligt förhållande

med en ond människa. ${ }^{298}$

O kung, om du är en person som följer

den stora farkosten,

där både sūtra- och mantrafarkosten ingår,

förverkliga då ditt eget och andras väl,

nu och i framtiden.

Och för att direkt klargöra orsak och verkan

ber jag dig tillintetgöra orättfärdighet

genom att straffa dem som begår dåliga handlingar.

Om du tillintetgör orättfärdighet, genom att straffa dem som begår dåliga handlingar, samlar du förtjänst i detta liv, såsom förklarats ovan. 
Att direkt demonstrera orsak och verkan är den högsta förtjänstfulla handlingen.

Eftersom det är till nytta för många, är tillintetgörandet av orättfärdighet genom att straffa dem som begår dåliga handlingar, meningsfullt för kungar i allmänhet, både nu och i framtiden.

Det är något som rättfärdiga kungar ska ägna sig åt, och i synnerhet, Dönyö Dorje, måste du, som är konung över de snöhöljda bergens rike, utöva på detta sätt!

Må ditt rike, ditt följe, ditt folk, och ditt rikes tillgångar, inte avta utan stadigt tillväxa och blomstra!

Evam!

Sången gjorde att dharmakungen återigen fylldes av en överväldigande hängivenhet gentemot Tsangnyön. 


\section{DE SISTA VAJRAFRASERNA}

Därefter begav sig mästaren och hans lärjungar till Yarlung. Genom sin utövning av den djupa vägen ${ }^{299}$ uppnådde denne helige och upphöjde individ regnbågens himmelska sfär under ett liv och i en kropp. När hans upplysta sinne smälte samman med rymden i Rechungpuk, en utövningsplats välsignad av Rechung Dorje Drakpa, ${ }^{300}$ uttalade han dessa sista vajrafraser:

$\mathrm{Nu}$, på min dödsbädd, efter att ha utfört en mängd förberedelser inför dödsögonblicket, är inget annat nödvändigt. Om ni lyssnar till mina ord så ska ni ägna hela livet åt utövning. Genom detta uppfyller ni inte bara mina, utan alla buddhors och bodhisattvors intentioner.

Munkar, lärjungar och välgörare, eftersom ni har mött Milarepa personligen i denna degenererade tidsålder, så har ni god karma och stor lycka. Fortsätt att läsa Milarepas livshistoria och ägna era liv åt utövning! Där finns mitt verkliga tal, och ni kommer att bli omhändertagna. Den skapades från dharmatā.

Evam! $!^{301}$

Sådana var Tsangnyöns sista ord. Detta var de sex välkända storslagna sångerna och de tjugoen sångerna med muntliga instruktioner, sammanlagt tjugosju sånger. 


\section{KOLOFONER}

Emaho!

Vår värld är trots allt lidande ett rent land, eftersom en buddha har fötts här.

På dess norra sida finns kontinenten vars kännetecken är rosenäppelträd. ${ }^{302}$ Här finns ett land som är vackert smyckat av ett pärlband med snöberg. ${ }^{303}$

I detta särskilt rena land har varelserna tyglats av Lokeśvara, den högsta ädla tillflykten och befriaren. Här finns Buddhas djupa förkunnelser och insikter samlade, likt ett brusande hav.

I havets mitt finns ett dyrbart palats.

Där, på de tre självuppståndna och obegränsade heliga snöbergen, finns nāgornas konung, Tsangpa, ${ }^{304}$ den högste fullkomnade mästaren. Tsangnyön är herren över hela detta hav. Havet är alla de buddhistiska läror som förkunnats och förståtts.

Från alla dessa skatter och från den dyrbara djupa meningen som uppfyller alla tänkbara önskningar, medkänslans blomstrande rikedom, samlade de lyckligt lottade hjärtesönerna, likt kaptener, med hjälp av hängivenhetens mirakulösa skepp, gradvis ihop Tsangyöns sånger. Efter att denna dyrbara önskeuppfyllande juvel avlägsnat [okunnighetens] all fattigdom åtnjöt de den djupa meningens strålglans. 
Efter att ha tagit bort upprepningar och lagt till sådant som saknades, och utan att glömma något, arrangerade den stora modern, Kunsang, ${ }^{305}$ denna dyrbara girland som uppfyller alla behov. Kuntu Sangmo arrangerade sångerna fram till instruktionerna till hjärtesonen Chöchok. ${ }^{306}$ Hon gjorde detta i den vördades närvaro. ${ }^{307}$

Utan återhållsamhet skänkte också Kuntu Sangmo allt som behövdes i samband med den hängivet utförda tryckningen av Sångernas juvel. ${ }^{308}$

För att avlägsna all fattigdom lät hon allt det som behövdes och önskades strömma över Tsangnyöns lyckosamma följeslagare, som vore det ett regn.

Tryckningen av sångerna utgör höjdpunkten av Kuntu Sangmos, den stora moderns, emanationens, högsta intentioner.

Sångerna är segerbaneret som kröner palatset som gagnar andra.

Med hjälp av visdomens väldoftande vatten och med de högsta intentionernas händer avlägsnade hjärtesonen Lopen Chöje oklara och felaktiga språkliga formuleringar. ${ }^{309}$

Med hängivenhet och goda intentioner sammanställde Götsangrepa dessa strålande och felfria sånger - Den önskeuppfyllande juvelen.

Götsangrepa gjorde detta för att sångerna är meningsfulla och eftersom han var bemyndigad att genomföra detta arbete. Han sammanställde sångsamlingen från och med instruktionerna till dharmakung Samde och framåt. ${ }^{310}$ 
Han avlägsnade fel och oklarheter beträffande meningen och uttrycket såväl före som efter denna sång, och han gjorde detta i enlighet med den vördades undervisning.

Genom den fulländade godheten som uppstått på grund av detta arbete, må alla varelser snabbt uppnå Tsangpa Herukas ojämförbara nivå. Han som förkunnat skrifterna och insikten, nått saṃsāras slutpunkt, samt uppnått de åtta högsta krafterna. ${ }^{311}$

Därefter må existensens ocean, tillvarons tre världar, fullständigt förtorka.

Genom kraften av de två sanningarna samt den ömsesidiga beroendeuppkomstens osviklighet, må dessa rena önskningars oöverträffade intentioner förverkligas!

Bokstäverna i den juvellika sångsamlingen skrevs ner av den mycket skicklige Namka Töpa Pele från Menkab.

Han utförde arbetet med de tre portarna helt fokuserade, full av hängivenhet och med fulländad intention.

De skickligt utförda träblocken som användes vid tryckningen karvades med stor noggrannhet av fyra av de mest framstående träsnidarna från Zurtso, ett område i södra Latö:

Sangye Gyaltsen, Dorje Pal, Norbu Yang Pal och Gendun Gyaltsen. ${ }^{312}$

Må också all den fulländade förtjänst som nedtecknandet av bokstäverna och träkarvandet medfört, göra att varelserna som fyller hela himlen får njuta av lycka, glädje och välstånd i detta liv, och därefter snabbt uppnå det fullkomliga uppvaknandet. 
Dessutom må alla varelser som fyller himlen fullända alla kroppens, talets och sinnets goda egenskaper hos Sangye Gyaltsen, lärans herre. ${ }^{313}$

Därefter, må de rena alla buddhaländer och föra alla varelser till mognad och befrielse!

Evaṃ mañghalaṃ bhawantu śubhaṃ! 